\title{
People and fish: Late Holocene rock art at Wulk Lagoon, Arnhem Land
}

\author{
Daryl Wesley, Tristen Jones and Rose Whitau
}

\section{Introduction}

Taçon and Brockwell (1995) made an important contribution to the study of Arnhem Land archaeology by showing that, in combining rock art with environmental change, archaeological sequences and artefact assemblages, a multi-disciplinary synthesis for a regional archaeological narrative could be achieved. A similar approach was taken by David and Lourandos (1998) in an overview of rock art and archaeology in Cape York Peninsula, northern Queensland. This chapter proposes to examine the rock art of the Wulk Lagoon area, northwestern Arnhem Land, by using approaches discussed by Taçon and Brockwell (1995) and David and Lourandos (1998) to analyse rock art, with a methodology that includes reference to environment, ecology and climate change along with local archaeological sequences from excavated rockshelters.

The late Holocene archaeological record of Arnhem Land is abundant, owing to high levels of Aboriginal occupation around the extensive wetlands and on the Arnhem Land plateau. Investigations of stone artefact assemblages in Australia have utilised approaches such as manufacturing technologies and proliferation events apparently linked to El Niño/Southern Oscillation (ENSO) and subsequent responses to risk in a context of environmental change (see Attenbrow et al. 2009; Clarkson 2002, 2007; Hiscock 2002, 2008, 2011; Hiscock and Attenbrow 1998, 2005; Lamb and Clarkson 2005; Veth et al. 2011). Residential mobility has also been assessed through characteristics such as the diversity and abundance of cultural materials in archaeological assemblages (see Andrefsky 2005, 2009; Kintigh 1984, 1989; Thomas 1973, 1989). In our case, here we try to understand Aboriginal occupation and behaviour in the Wulk Lagoon area, on the East Alligator River, over the past 1500 years via the distribution of its rock art (Figure 2.1).

Previous archaeological investigations in the region have usually paid minor attention to the rock art (see Allen and Barton 1989; Hiscock 1999, 2008, 2011; Schrire 1982). Hiscock (2008) has repeatedly pointed out that the art encodes valuable information, but identifies current shortcomings for true archaeological interpretation. Nevertheless, valuable advances in rock art research elsewhere have drawn on climate and environmental change (see McDonald 2015; McDonald and Veth 2013), pigment studies (see Huntley 2012; Huntley et al. 2014; Wesley et al. 2014) and 'direct' dating (see McDonald et al. 2014; Smith et al. 2009; Watchman 2000; Watchman and Jones 2002; Watchman et al. 1997, 2010). Each provides valuable information, allowing rock art to be better integrated into discussions of Aboriginal pasts. 


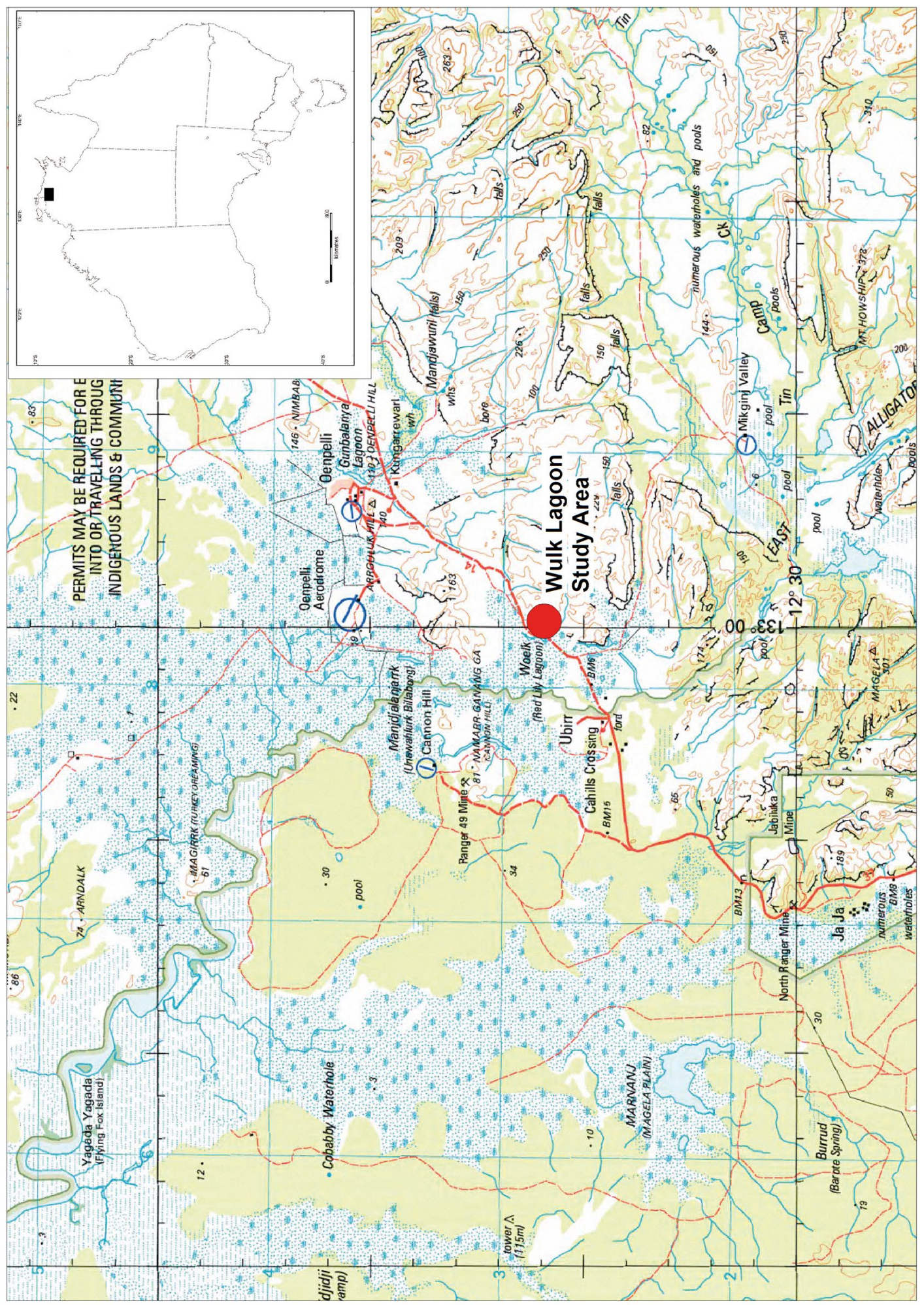

Figure 2.1 Location of Wulk Lagoon study area, western Arnhem Land, Northern Territory.

Source: Base map after SD-5301 Geoscience Australia. @ Commonwealth of Australia (Geoscience Australia) 2015. This material is released under the Creative Commons Attribution 4.0 International Licence. 
At Wulk Lagoon, faunal themes are well evident, especially fish. Fish and other animals not only represent food resources, but also reference points for more esoteric aspects of life, as we know from ethnography both here and elsewhere. In the East Alligator River region, fish signal estuarine and freshwater ecologies and the widespread geomorphological changes that took place during the mid to late Holocene. Wulk Lagoon's rock art also contains many examples of the anthropomorphic 'Energetic Figure' (Taçon 1989a, 1989b), 'Complete Figure', and 'X-ray' styles (see Chippindale and Taçon 1993, 1998) (for descriptions of the various art styles mentioned in this chapter, see Wesley 2015). The emergence of these rock art styles, or manners of depiction, their variation and their distributions across the landscape are important for understanding late Holocene occupation of the region. We thus ask of Wulk Lagoon's rock art:

- Was it evenly produced across the landscape during the late Holocene?

- To what degree have climate and environment influenced human occupation and mobility, and how can the art aid us in this quest?

- Through time, did the positioning of rock art change across the landscape?

- What were the major subjects expressed in the art, and did these vary across space or change through time?

- Within rockshelters, was the rock art produced during occupation, or were the two largely mutually exclusive?

Significant changes in the environment and ecology of the East Alligator River have previously been noted for the period following sea level stabilisation c. 6000 years ago (e.g. Chappell 1988; Chappell and Grindrod 1985; Clark and Guppy 1988; Grindrod 1988; Hope et al. 1985; Russell-Smith 1985a, 1985b; Wasson 1992; Woodroffe 1988; Woodroffe et al. 1985a, 1985b, 1986, 1987, 1988). Archaeological research nearby has shown the subsequent dramatic impacts of marine and estuarine change on human occupation and mobility, on the plains and on the plateau generally (Allen and Barton 1989; Bourke et al. 2007; Brockwell 1989, 1996; Hiscock 1999; Hiscock et al. 1992; Jones 1985; Kamminga and Allen 1973; Meehan et al. 1985; Schrire 1982). The last 6000 years saw new economic strategies develop, presumably to deal with these environmental changes, but also in response to social conditions. Excavations at rockshelter sites such as Birriwilk, Ngarradj Warde Djobkeng, Malakunanja II (Madjedbebe), Nawamoyn, PariPari and Jimeri (Jimede) clearly show the changes that occurred in diet, occupation and stone tool technologies (see Figure 1.1 for site locations) (Allen and Barton 1989; Hiscock 1999, 2011; Kamminga and Allen 1973; Schrire 1982; Shine et al. 2013). However, these excavations tell us much less about changes in rock art for that same period of time.

Wulk Lagoon's rock art appears to be consistent with Chaloupka's (1977, 1984, 1985, 1993) sequence of major rock art styles that followed post-glacial sea-level rise. But there are also limitations to attributing, reducing even, stylistic change to environmental change (see Chippindale and Taçon 1998; Lewis 1988). The late Holocene rock art is diverse and abundant, even within broad stylistic phases (Chaloupka 1977, 1984, 1985, 1993; Chippindale and Taçon 1998; Lewis 1988; Taçon 1989a, 1989b), and preservation has played its part. Nevertheless, it presents a rich opportunity to examine depictive or symbolic aspects of culture and cultural diversity, and in relation to occupation.

\section{The study area: Wulk Lagoon}

To investigate degrees of abundance and diversity in depictive behaviour - how people marked the land - a $3.5 \mathrm{~km}^{2}$ sandstone outcrop next to Wulk Lagoon was surveyed on the western side of the East Alligator River's coastal plain (Figure 2.1). Wulk Lagoon is in the traditional estate of the Manilakarr clan of the Erre language group. It and nearby palaeo-channels form important 
water features parallel to the northwestern edge of the sandstone plateau. It is in Mamadewerre Sandstone (part of the Kombolgie Sub-Group), a cross-bedded quartzose sandstone with medium to very coarse grain, and siliceous sandstone. Outcropping rock is generally found as sandstone tors, platforms and escarpment features (Duggan 1994; Needham 1984; Senior and Smart 1976; Sweet et al. 1999). The sandstone outcrop at Wulk Lagoon is bounded by extensive coastal plains of the East Alligator River, rich in alluvial sediments with large lagoons, palaeo-channels and Melaleuca sp., Eleocharis dulcis and Oryza rufipogon-dominated swamps and sedge-lands.

The Wulk Lagoon area first came to prominence for its rock art during the 1948 AmericanAustralian Scientific Expedition to Arnhem Land through a number of publications by Charles Mountford (1956, 1964, 1965, 1975). The outlying sandstone hills next to Wulk Lagoon were called 'Inagurdurwil' by Mountford (1956). This is a name that is not recognised by Manilakarr Traditional Owners today; Gunn (1992) suggested that it may have been provided by an Aboriginal informant from Gunbalanya rather than by an Erre speaker. Mountford was particularly attracted to the detailed hunting scenes in the art, discussing them in detail along with the greater significance of the rock art seen during the expedition. These scenes and motifs at the Inagurdurwil galleries include images of running figures and men hunting (see Bühler et al. 1965:209). Mountford $(1964,1965,1975)$ discussed techniques, materials and pigments used to make rock art in the region, using Inagurdurwil as a primary example. He refers to the rock art of western Arnhem Land as by far the most colourful he had encountered in Australia, again with specific reference Inagurdurwil (Mountford 1964:12).

Fred McCarthy (1965) was also part of that same 1948 expedition; he provided an overview of the archaeology. Some of the material he wrote about includes rock paintings from western Arnhem Land, X-ray and 'spirit' paintings, and painted caves at Red Lily (Wulk) Lagoon and elsewhere on the Manilakarr estate. McCarthy (1965) discusses 'Mormo' and 'Mimi' spirits, and reports X-ray paintings from Inagurdurwil, along with descriptions of the purposes of magic, increase rites and the education of boys, each a significant feature of cultural knowledge for Manilakarr Traditional Owners. Further research at Wulk Lagoon was later undertaken by Jan Jelinek. Jelinek (1986) incorporated Inagadurwil in his general schema of western Arnhem Land rock art, studying rock art sites Inagurdurwil I to VI in particular. His stylistic identifications, chronological assessments and interpretations of the archaeological significance of these sites are highly problematic, as they were made without reference to previous research while making highly improbable stylistic chronologies. Later, in 1990, Gunn (1992) undertook a detailed survey of surrounding parts of the Manilakarr estate, recording rock art imagery from numerous sites, including several at Wulk Lagoon. He documented sacred and cultural knowledge relating to Dreaming images and Spirit-Beings, such as Birriwilk ('old lady'), Rainbow Serpent (Ngalyod), barramundi, malevolent spirits (Namarodo and Marlwah), 'old hairy spirit' (Djidjnguk) and 'scarecrow figure' (Djiworrn Djiworrn).

\section{Western Arnhem Land during the late Holocene}

Previous archaeological discussions by Allen and Barton (1989), Brockwell (1989, 1996), Hiscock (1999), Hiscock et al. (1992), Jones (1985), Meehan et al. (1985), Schrire (1982) and others all refer to important Holocene environmental transformations for the region. Initial postglacial sea-level rise would have affected Aboriginal economic and, probably, social order, given the vast exposed landscapes that came to be inundated by rising seas. Since then, the past c. 6000 years saw two major environmental phases along the Alligator Rivers: a major 'Big Swamp' phase (c. 6000 to $4000 \mathrm{BP}$ ) followed by 'Sinuous' and 'Cuspate' phases (4000 BP to present), which, in due course, came to see a 'Freshwater' period of wetland development (1500 BP to present) (Allen and Barton 1989; Jones 1985; Kamminga and Allen 1973; Schrire 1982). Throughout

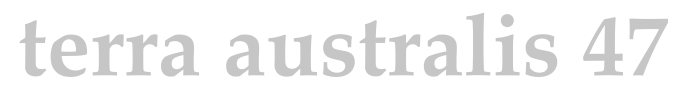


this time, Aboriginal people continued to occupy the region, as indicated by archaeological deposits in rockshelter sites at and near Wulk Lagoon, including the Birriwilk site a short distance south (Shine et al. 2013). Shine et al. (2013:72) dated the initial use of the Birriwilk shelter c. 4865-5065 cal BP, with occupation continuing into the European-contact period.

Archaeological research in late Holocene wetlands of the nearby plains found ecological diversity to be as important as biomass for Aboriginal settlement (Brockwell 1989; Brockwell et al. 2001; Guse 1992; Hiscock et al. 1992; Meehan et al. 1985). Resource biodiversity is usually highest along ecotonal margins between environmental zones. Archaeological studies have demonstrated that ecotones between coastal plains and sandstone plateaux, such as at Wulk Lagoon, provided attractive environments for occupation (Allen and Barton 1989; Hiscock 1999; Jones 1985; Schrire 1982). Such ecotones helped structure resource distributions, and therefore affected the mobility of resident and visiting groups. Areas of higher ecological diversity and resource abundance were targeted, forming sustained subsistence-settlement strategies that made their mark on the archaeological record (Allen and Barton 1989; Brockwell 1989, 1996; Hiscock 1999; Hiscock et al. 1992; Jones 1985; Meehan et al. 1985; Schrire 1982). Archaeological sites located at such ecotones, and in areas of high biodiversity and resource abundance, have thus been found to have substantial archaeological records, including rock art. But whereas these past studies have focused on faunal remains and stone artefacts, here we examine the art on the rocks.

\section{Environmental change during the late Holocene}

A number of geomorphological studies have investigated landscape history in the greater Alligator Rivers region (see above), but there are currently no palaeo-environmental reconstructions specific to the East Alligator River at Wulk Lagoon. The closest research occurred c. $13 \mathrm{~km}$ west, at Magela Creek, which focused on the ecological history of this backwater swamp and palaeotributary of the East Alligator River (East et al. 1987a, 1987b). Pollen evidence and radiocarbon dates from mangrove muds and shell middens in the Magela floodplain suggest a longer Big Swamp phase for the western East Alligator River region than for the South Alligator River, with Rhizophora forest dominating the pollen record from c. 8000 to 3000 BP (Clark and Guppy 1988:680-681). The Sinuous phase, which Clark and Guppy (1988:680-681) define as a transitional period from mangrove forest to freshwater wetland, has a later and slightly shorter record in the Magela floodplain than in the main South Alligator River region, lasting c. 1700 years from 3000 to $1300 \mathrm{BP}$. The increase in sedimentation rates during this period, together with a subsequent phase of levee formation, may also be related to an increase in precipitation and seasonality (Denniston et al. 2013; Lees and Clements 1987). This transitional period, which experienced maximum environmental instability, produced the greatest vegetation diversity and variability of the Holocene (Clark and Guppy 1988:680-681). This has major implications for understanding changing patterns of Aboriginal occupation.

\section{Climate change during the late Holocene}

Faulkner $(2009,2011)$ notes that across northern Australia, Holocene climate change occurred in tandem with sea-level rise, and stabilisation strongly influenced coastal ecology. Denniston et al. (2013) show that past activity of the Indonesian-Australian Summer Monsoon (IASM), InterTropical Convergence Zone (ITCZ) and El Niño/Southern Oscillation (ENSO) may have driven precipitation variability since at least the mid-Holocene. In particular, the IASM strengthened during the early Holocene, with enhanced peak rainfall between 8000 and 4000 years ago, with a possible phase of increasing aridity from 6300 to 4500 years ago. This was followed by a decrease in IASM strength around 4000 years ago, leading to lower rainfall. Denniston et al. (2013) found peak aridity between 2000 and 1000 years ago, followed by a strengthening IASM developing 
into the pattern we experience today. There is also evidence from Magela Creek and the Daly River indicating a significant dry phase lasting c. 160 years from 690 to 530 BP (Wasson et al. 2010:172).

Increasing and decreasing precipitation have major impacts not only on vegetation and faunal communities, but also on rates of sediment accumulation across the landscape, and on the evolution of rivers and coastal systems. In contrast to fluctuating climates, studies of plant species in plateau ravines have revealed that long-lived floristic communities survived all the major climate changes since the Last Glacial Maximum (LGM), a result of the presence of permanent water sources and other factors (Russell-Smith et al. 1997). On this basis, it is likely that fluctuating precipitation driven by ENSO-IASM interactions saw continuity in floristic and faunal communities in dissected sandstone environments, despite a higher overall aridity. Lower precipitation rates can have significant impacts on riverine evolution, with reduced water flows unable to flush out sediments from the sandstone plateau, leading to the siltation of major river systems, thereby choking mangrove communities and establishing massive floodplains, such as at Wulk Lagoon (Chappell 1993, 1988; Woodroffe et al. 1993). These late Holocene fluctuations in IASM precipitation would have aided the proliferation of freshwater swamps and wetlands, significantly influencing shifts in woodland communities.

\section{Recent rock art research in Arnhem Land}

Archaeological research has shown the great length of Aboriginal occupation across the 'Top End' of the Northern Territory (e.g. Allen and Barton 1989; Bird et al. 2002; Brockwell et al. 2009, 2011; Clarkson et al. 2017; David et al. 2012; Delannoy et al. 2013; Geneste et al. 2010, 2012; Gunn and Whear 2007a, 2007b; Gunn et al. 2010a, 2010b, 2011; Hiscock 1999; Hiscock et al. 1992; Jones 1985; Meehan et al. 1985; Roberts et al. 1990; Schrire 1982; Shine et al. 2013). At Nawarla Gabarnmang, a small piece of quartzite with charcoal lines was retrieved from buried sediments dated to 27,000-28,000 cal BP, one of the oldest dated painted images in Australia (David et al. 2012). Around that time, Aboriginal people were actively modifying the shape of the shelter by knocking down rock pillars to expand the space within (see Chapter 10). Gunn et al. (2012) further document that, during the late Holocene, rock art at this site included a range of conventions, including what they termed 'Northern', 'Bula' and 'Jawoyn' styles, indicating multiple signalling behaviour at a single site. The Nawarla Gabarnmang research demonstrates how one site or site complex can reshape our understanding of rock art and Aboriginal occupation of the Arnhem Land region.

At the other end of the time scale, to the north of both Nawarla Gabarnmang and Wulk Lagoon, in the coastal sandstone of the Wellington Range, major archaeological and rock art results have also changed our way of thinking: in this case, as it relates to the period of culture contact between Macassans, Europeans and Aboriginal peoples (Clark and May 2013; May et al. 2010, 2011; Taçon et al. 2010; Theden-Ringl et al. 2011; Wesley 2013; Wesley et al. 2012). Analysis of painted ships and firearms caused us to rethink the involvement of Aboriginal people in maritime and terrestrial industries in northern Australia (Wesley 2013; Wesley et al. 2012). 


\section{Methods}

\section{Rock art styles as chronologies}

As noted above, there has been a significant amount of research on Arnhem Land's rock art since the 1960s, leading to the identification of a number of major styles and chronologies (e.g. Brandl 1970, 1980; Chaloupka 1984, 1985, 1993; Chippindale and Taçon 1998; Edwards 1979; Jelinek 1986; Lewis 1988; Taçon 1989a, 1989b). These regional style chronologies have not made much use of absolute chronometric dates, except in the case of beeswax figures (e.g. Taçon et al. 2004). Although Rosenfeld and Smith (1997:407) note that using 'style' can be problematic for the definition of chronologies, they also emphasise its value when rigorously applied.

Here we rely largely on Chippindale and Taçon's $(1993$, 1998) revised style chronology for western Arnhem Land. In a study such as ours at Wulk Lagoon, we need to be clear as to how style, and age, are given to the art, for we are working without absolute dates. Chaloupka (1993), Chippindale and Taçon (1998), Lewis (1988) and Taçon's (1988) identifications of late Holocene art styles, for example, have significantly affected how most, and perhaps all, researchers think of the sequence of stylistic conventions for this broad period of time (see the chronological table in Chippindale and Taçon 1998:107). As Chippindale and Taçon (1998) note, the Arnhem Land sequence has been developed mostly by seriating superimposed classes of painted motifs (cf. Lyman and O'Brien 2006). This includes both the presence and absence of fauna known, or thought, to have been associated with particular environmental conditions (Chaloupka 1993) and weaponry (Lewis 1988). These were perhaps the most viable approaches available to researchers since critical analysis of Arnhem Land rock art began in the early 1970s. Formal analyses of Rainbow Serpents, 'Yam' figures, and X-ray motifs have added to this schema, with links to climate and environmental change (Chaloupka 1993; Chippindale and Taçon 1998; Taçon 1994; Taçon and Brockwell 1995; Taçon et al. 1996).

Although each chronological model has its problems and limitations (see Bednarik 2012, 2014a, 2014b), the Arnhem Land style chronologies proposed by the above authors largely converge towards a broadly acceptable temporal schema (Figure 2.2), with all researchers also recognising that absolute dates are required to better understand the 'real' age of each style.

\section{Survey strategy}

Wulk Lagoon provides an important lens for the archaeology of art at the interface of the Stone Country and the extensive coastal plains. This is a varied landscape, where questions of taphonomy are important for understanding the frequency of art and of art styles and conventions. To deal with such questions, a small sample area was intensively surveyed at Wulk Lagoon as a way of assessing how the larger rock art galleries that preferentially feature in the archaeology, and focal research areas in the escarpment base, compare to the whole. Also to be considered is the three-dimensional nature of the rock escarpment. Rock art occupies a complex space in this landscape, where elevated areas erode and valleys tend to accumulate rocks and finer sediments (see Chapter 1), so we divide the study area into three major zones: the escarpment base, the steeply eroded sides and the rocky hilltops. This enables us to provide samples from different geomorphological, and erosional/depositional, zones. Of particular interest is whether the late Holocene saw all these zones used for rock art production and occupation. By stratifying the survey area in this way, we could also test for preservation and occupation bias in the resulting patterns. 


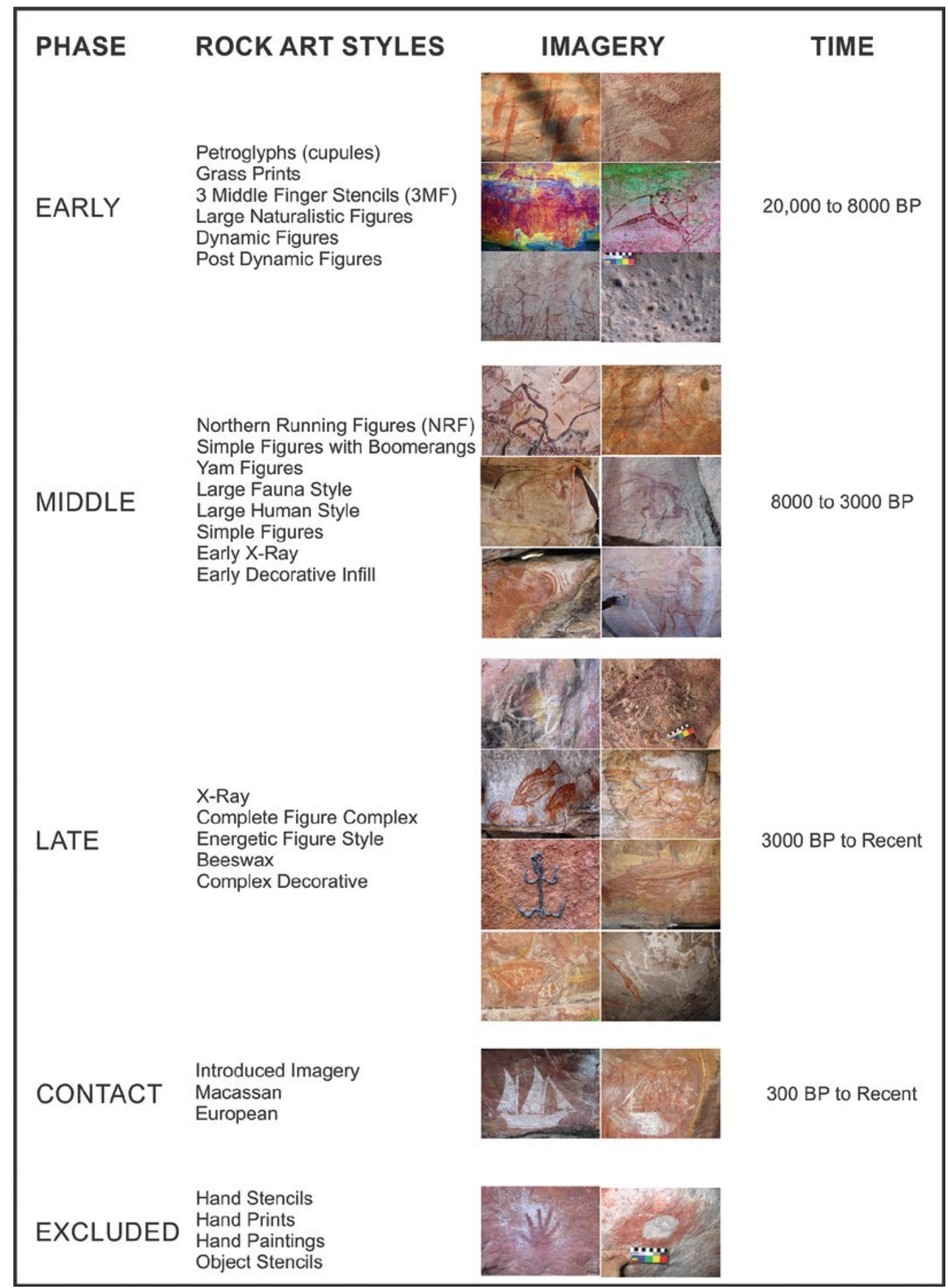

Figure 2.2 Composite rock art phases.

Source: After Chippindale and Taçon (1998:107), with amendments after David et al. (2012) and Gunn et al. (2012). 


\section{Assessing mobility}

A number of analytical techniques have been developed to model mobility and intensities of site use (e.g. Andrefsky 2005; Baxter 2001; Kaufmann 1998; Kintigh 1984, 1989; Thomas 1973, 1989). Many make use of measures of resource diversity and/or richness in the environment, or as evident in the archaeological record. Two properties are usually considered: the number of distinct classes present; and their degree of evenness or uniformity (Kintigh 1989:26). Thomas (1989:86) proposes that the overall relationship between the number of archaeological classes and the number of individual items is influenced by ecological, technological, informational (i.e. 'traditional ecological knowledge') and scheduling factors. He describes three types of sites, distinguished (and measurable) by their archaeological richness: single-use/activity-specific sites, short-term occupation sites and long-term occupation sites. Frequently occupied sites are identified by technologically and typologically diverse stone tool assemblages that might have been used for many purposes, and over long periods of time. Less frequently occupied sites were usually used for more ephemeral, more specific, even single tasks; they have less diverse stone tool assemblages than the more frequently occupied sites. Infrequently occupied sites were even more task-specific, and here stone tool assemblages are the least diverse and least abundant (Thomas 1989:86).

Does this kind of diversity and richness modelling also apply to rock art, and to the rock art sites of Wulk Lagoon? To explore this, we apply Thomas's (1989) principles of frequency and abundance of stone artefacts to the art. The production of rock art involves the use of materials, and it takes time and energy, much like the production and use of stone tools does. We would thus expect the greatest diversity and frequency of rock art styles, motifs and elements to occur also at the most frequented places (Thomas 1989:86). The archaeological classes we use are the rock art styles, anthropomorphic motif types and elements and zoomorphic motif types. Places where rock art was frequently produced are predicted to be rich and diverse in their art styles, motifs and elements; less frequented sites to have intermediate levels of diversity and abundance; and rarely visited places, low diversity and low abundance. Applying these principles of diversity and abundance to rock art may provide a new way of investigating patterns of visitation and engagement, including aspects of occupational intensity not previously considered in Australian rock art research.

\section{Taphonomy}

All archaeological assemblages in Arnhem Land possess taphonomic limitations. Owing to high rainfall levels associated with the IASM, and the predominantly sandy soils, faunal remains and other organic materials are usually poorly preserved (see Jones 1985; Schrire 1982). Highly seasonal climates see annual cycles of drying and wetting, burrowing animals and high levels of soil mobility and/or soil acidity - all poor conditions for the preservation of organics (see Bourke 2000; Brockwell 2009; Gregory 1998; Guse 2006; Mowat 1994, 1995). Therefore, the potential for long-term preservation of both on-wall art and buried pigments requires systematic assessment.

At Wulk Lagoon, a number of pigment types have been found, some in reasonable quantities, during excavations: ferrous oxides and haematite (reds, orange), kaolinite (white), whelwellite (white), kaolinitic claystone (white, red, yellow, orange) (Chaloupka 1993; Taçon 1989a, 1989b; Wesley et al. 2014). Claystone, whelwellite and kaolinite pigments are thought not to preserve well, in part because they are soluble in water. This has often led researchers to assume that paintings (and motif types) made with such pigments date to the mid to late Holocene, but not earlier, for surely they would have disintegrated since then. Climatic regimes with annual wet tropical monsoons will have quickened the dissolution of these soluble pigments, and the strengthening of the IASM through the mid to late Holocene with increased seasonal rainfall 
would have impacted on the art. The presence of white pigment in Arnhem Land rock art may not mean a late antiquity, but in more exposed conditions it more likely does, and thus helps in assigning a time frame.

\section{Results}

In 2011, a total of 77 rock art sites were recorded within the $3.5 \mathrm{~km}^{2}$ Wulk Lagoon study area, providing a mean density of 33.4 sites per $\mathrm{km}^{2}$ (Figure 2.3). In this region, we estimate there are 13,000 rock art motifs painted on approximately 460 sandstone panels. Eight rock art sites face the coastal plain, with the remainder 70 sites on the sandstone outlier itself. The majority of sites were found on the escarpment base, hillside, hilltop or on independent tor outcrops (Table 2.1). Of the 77 rock art sites, 44 are 'rock art panels' (rock art on one to three panels with no other archaeological features) and 33 are 'rockshelters'; this differentiation was made to assess the location of the art relative to the size and nature of its site context. Documented archaeological features include grinding hollows and surfaces, buried cultural deposits, stone arrangements, hearths, stone artefacts, stone quarries, faunal remains, human burials, 'contact' materials and wooden artefacts. Figure 2.4 shows their distribution at Wulk Lagoon. Table 2.2 indicates that, on average, only two archaeological features are present per site. An archaeological excavation was undertaken at Minjnymirnjdawabu 5 (MN05); in conjunction with the survey, it added valuable information regarding the timing of occupation and geomorphological processes at Wulk Lagoon.

Table 2.1 Geomorphological context of rock art sites.

\begin{tabular}{|l|r|}
\hline Context & \# of sites \\
\hline Bluff face & 2 \\
\hline Boulder & 3 \\
\hline Escarpment base & 18 \\
\hline Hillside & 24 \\
\hline Hilltop & 16 \\
\hline Tor & 14 \\
\hline
\end{tabular}

Source: Authors' data.

Table 2.2 Descriptive statistics for the 77 surveyed rock art sites at Wulk Lagoon.

\begin{tabular}{|c|c|c|c|c|c|c|}
\hline & $\begin{array}{c}\begin{array}{c}\text { \# of } \\
\text { archaeological } \\
\text { features/site }\end{array} \\
\end{array}$ & $\begin{array}{c}\text { \# of styles/ } \\
\text { site }\end{array}$ & $\begin{array}{l}\text { \# of zoomorphic } \\
\text { classes/site }\end{array}$ & $\begin{array}{c}\text { \# of anthropomorphic } \\
\text { classes and } \\
\text { elements/site }\end{array}$ & $\begin{array}{c}\text { \# of } \\
\text { motifs/ } \\
\text { site }\end{array}$ & $\begin{array}{l}\text { \# of rock art } \\
\text { panels/site }\end{array}$ \\
\hline Mean & 2.4 & 4.5 & 4.5 & 5.1 & 167.7 & 6.0 \\
\hline $\begin{array}{l}\text { Standard } \\
\text { deviation (SD) }\end{array}$ & 2.3 & 3.9 & 4.4 & 5.8 & 485.3 & 13.2 \\
\hline $\begin{array}{l}\text { Standard error } \\
\text { of mean (SEM) }\end{array}$ & 0.264 & 0.449 & 0.503 & 0.665 & 55.308 & 1.502 \\
\hline $\begin{array}{l}\text { Lower } 95 \% \\
\text { confidence limit }\end{array}$ & 1.85 & 3.58 & 3.46 & 3.75 & 57.38 & 2.96 \\
\hline $\begin{array}{l}\text { Upper 95\% } \\
\text { confidence limit }\end{array}$ & 2.90 & 5.37 & 5.47 & 6.40 & 278.02 & 8.95 \\
\hline Minimum & 1 & 1 & 0 & 0 & 1 & 1 \\
\hline Median & 2 & 3 & 3 & 3 & 15 & 2 \\
\hline Maximum & 12 & 19 & 19 & 24 & 3000 & 100 \\
\hline
\end{tabular}

Source: Authors' data. 


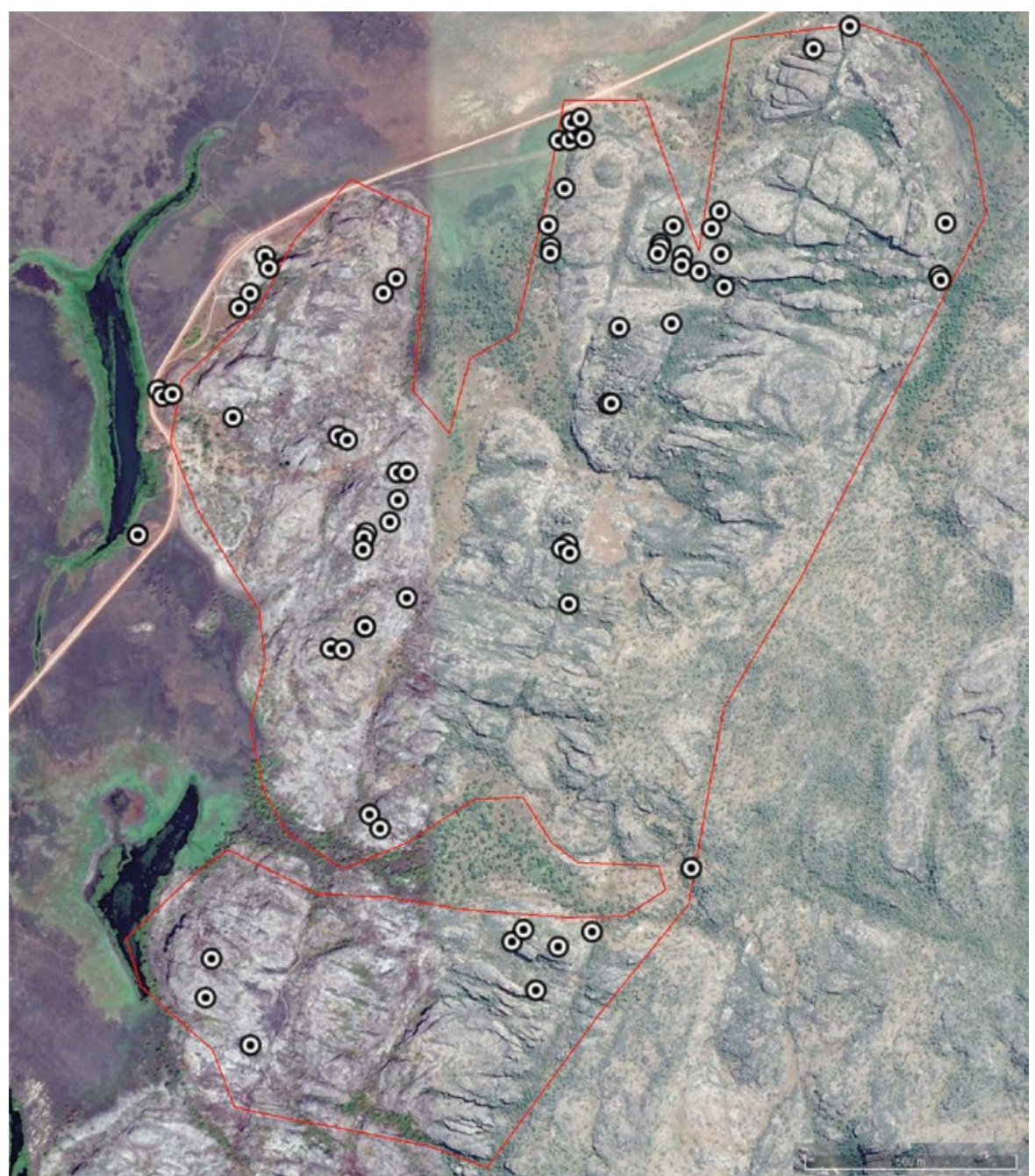

Figure 2.3 Survey area showing location of rock art sites.

Source: @ Google Earth 2014.

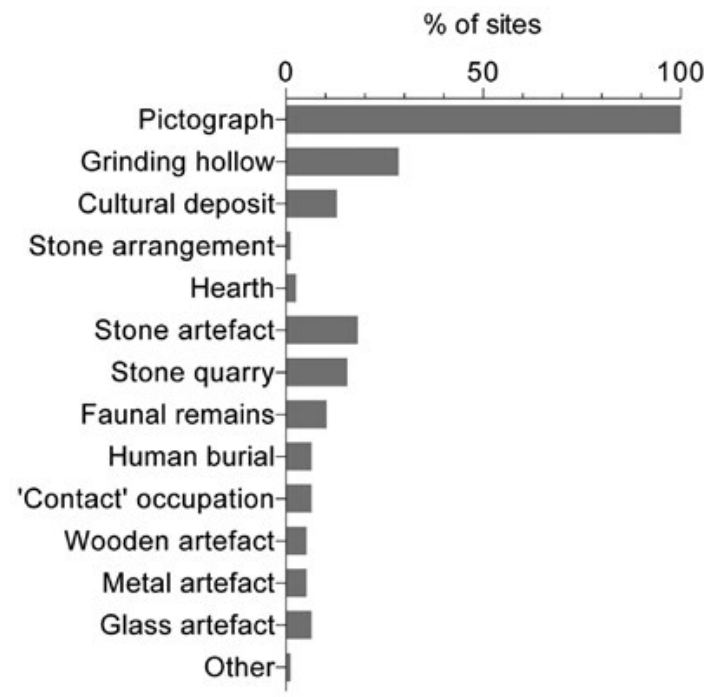

Figure 2.4 Types of archaeological materials present at rock art sites ( $n=77$ sites). Source: Jerome Mialanes. 
Table 2.2 provides descriptive statistics for the art. There are, on average, 4.5 rock art styles per site (median $=3$; maximum $=19$ ). Zoomorphs and anthropomorphs are evenly represented (in 84.4 per cent vs 83.1 per cent of sites, respectively, averaging 4.5 vs 5.1 per site). Eighteen sites have 100 or more images, the largest being RLB032 with c. 3000 (Figure 2.5). The median of 15 motifs per site is more indicative of the trend, as a high standard deviation of 485.3 shows considerable variation in numbers, which range from one to c. 3000 . The average number of panels per site is skewed by a few sites with high numbers.

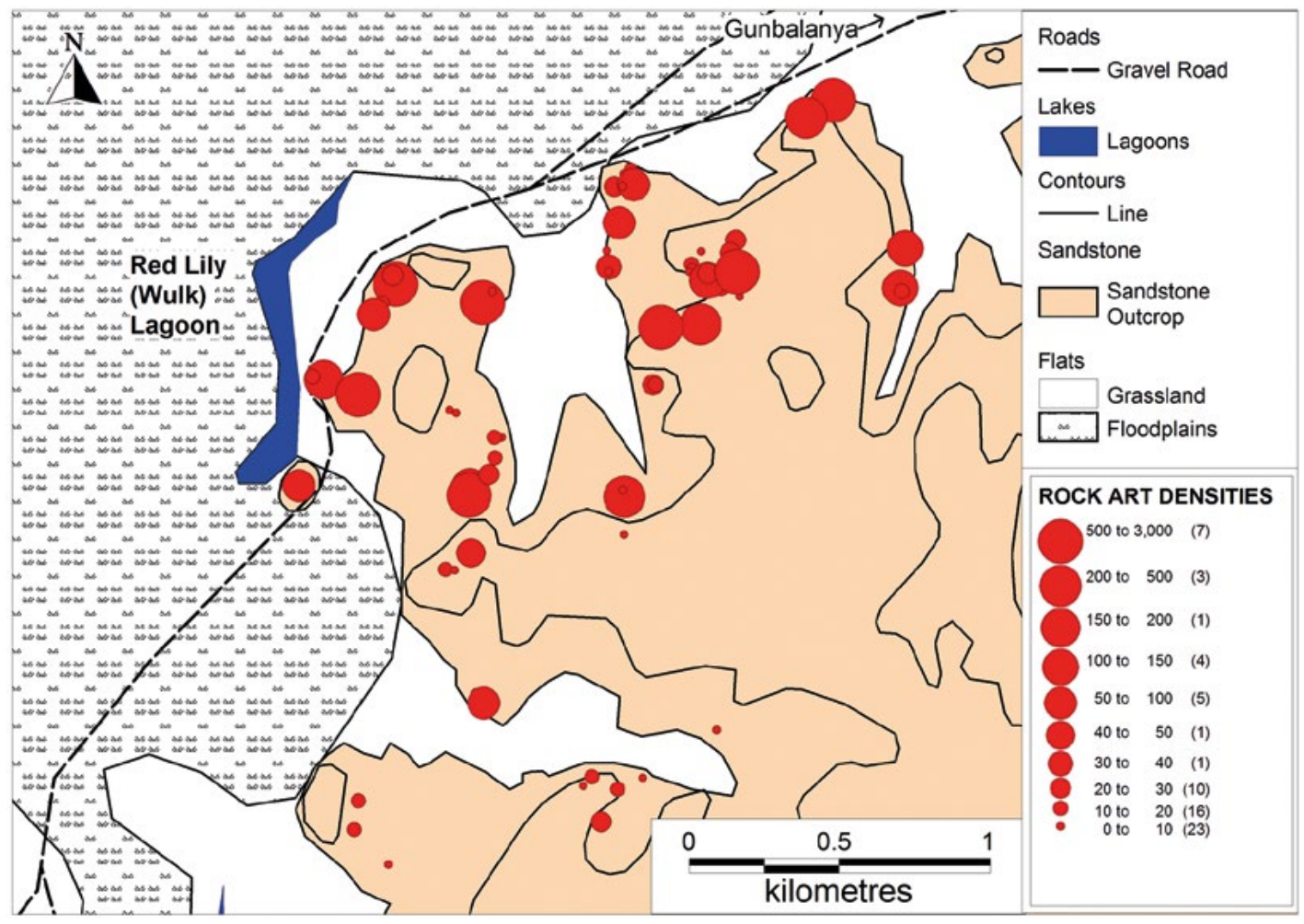

Figure 2.5 Distribution of rock art sites, showing number of artworks in each site.

Source: Daryl Wesley.

A broad range of rock art styles is found at Wulk Lagoon (Figure 2.6). Large Fauna, Large Human, Simple Figures and Complete Figure Complex paintings predominate, followed by X-ray, Early X-ray and Early Decorative Infill. Energetic Figure and X-ray motifs are most common in the major site complexes. Energetic Figures are especially common at the base of the rock outcrops, whereas X-ray and Complex Decorative figures are most common at the two major art complexes on top of the plateau. These three rock art styles clearly superimpose most others, indicating that they are amongst the most recent. Many rock art panels have multiple layers of superimposition.

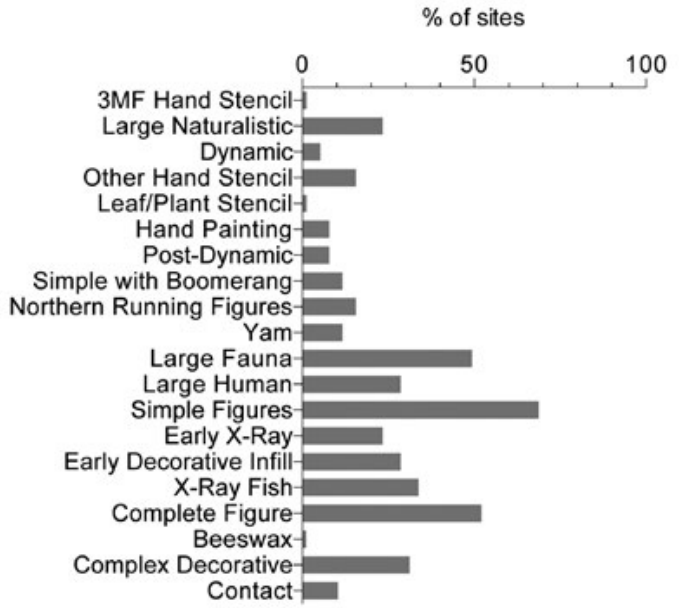

Figure 2.6 Proportion of sites with each rock art style ( $\mathrm{n}=77$ sites).

Source: Jerome Mialanes. 


\section{Zoomorphs}

Zoomorphs include dingo, marsupial, echidna, flying fox, macropod, reptile, goanna, frill-neck lizard, crocodile (freshwater and saltwater), snake, python, long-necked turtle, short-necked turtle, fish, thylacine and bird. Fish motifs are the most abundant; they are discussed at greater length below. Macropods, reptiles, birds, goannas and snakes are each present in more than 20 per cent of sites (Figure 2.7).

Paintings of fish occur in 55 sites. Taçon (1988:5) noted that 43 different native fish species are known from the Alligator Rivers region, with a dozen being consistently depicted in the rock art. He further found that most X-ray depictions are of barramundi, saratoga, fork-tail catfish, eeltail catfish and mullet. Other depicted species include the freshwater longtom, archer fish, black bream, boney bream and terapon perches or grunters (Tacon 1988:5).

Here we analyse 385 fish motifs from the art at Wulk Lagoon. Species include barramundi (Lates calcarifer), saratoga (Scleropages jardini), fork-tailed catfish (a.k.a. 'boofhead' catfish) (Hexanematichthys leptaspis), eel-tailed catfish (Neosilurus hyrtlii), mullet (Liza alata), freshwater longtom (Strongylura kreffti), archer fish (Toxotes chatareus), toothless catfish (Anodontiglanis dahli) and black catfish (a.k.a. narrow-fronted tandan) (Neosilurus ater) (Figure 2.8). Additional to these, many fish depictions could not be identified to species.

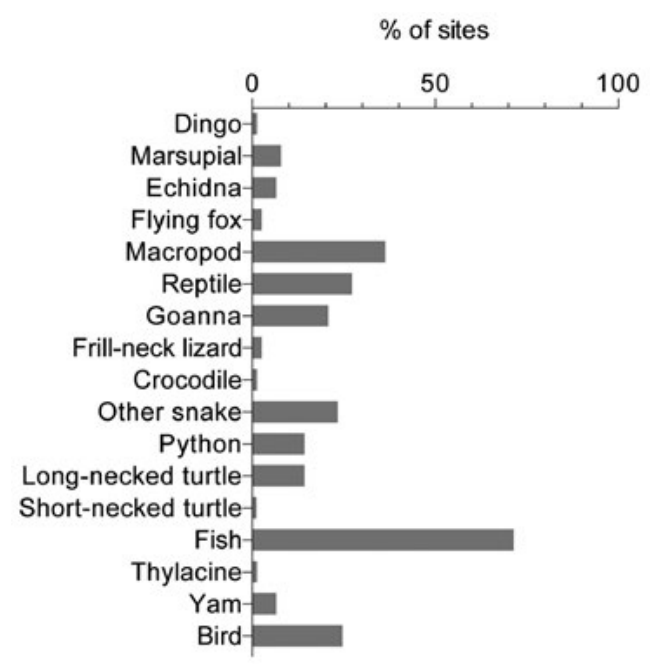

Figure 2.7 Proportion of sites with each type of zoomorph ( $\mathrm{n}=77$ sites).

Source: Jerome Mialanes.

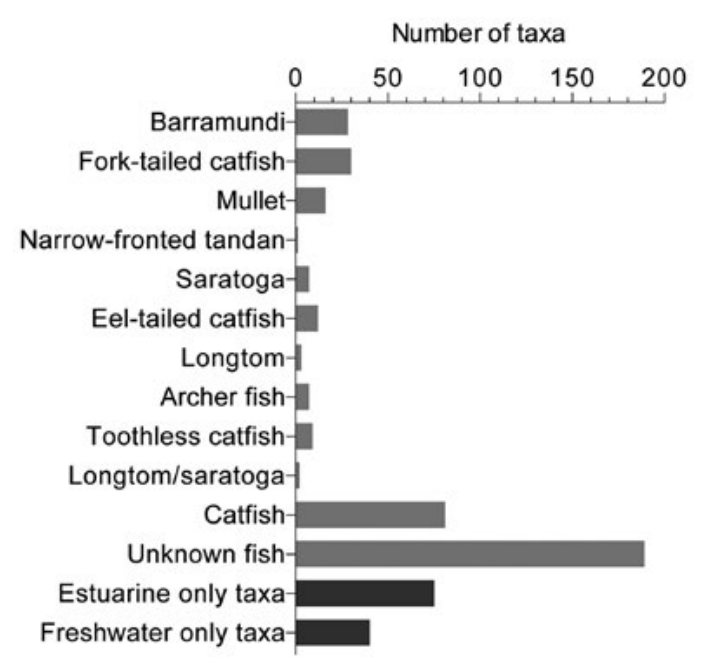

Figure 2.8 Number of paintings by fish taxa.

Source: Jerome Mialanes.

Figure 2.9 indicates the manner in which the fish were painted. The study found 54.5 per cent of the fish paintings were in a Late Phase-style. Estuarine species are more frequent than freshwateronly species. Fork-tail catfish, and catfish in general, are the most common. Their habitats can vary from brackish estuaries to only freshwater: for example, Hexanematichthys leptaspis inhabits both estuarine and freshwater habitats, whereas Neosilurus hyrtlii and Neosilurus ater only live in freshwater, be it still or flowing in streams, billabongs or pools.

The painted fish at Wulk Lagoon are associated with types of waterways that evolved locally only after post-glacial sea-level rise c. 8500-8000 BP (Woodroffe et al. 1985a, 1985b, 1986, 1988). Between 8000 and 3000 BP, the Wulk Lagoon sandstone headland became surrounded by wetlands, swamps and paleo-channels of the former East Alligator River (Hope et al. 1985:239). Large backwater swamps and billabongs are thought to have increased in number in the Alligator 
Rivers region after 3000 BP (Clark and Guppy 1988:680-681; Hope et al. 1985:240). Figure 2.9 also shows the distribution of fish paintings by geographic zone at Wulk Lagoon. There is a preference for sandstone hillsides and hilltops.

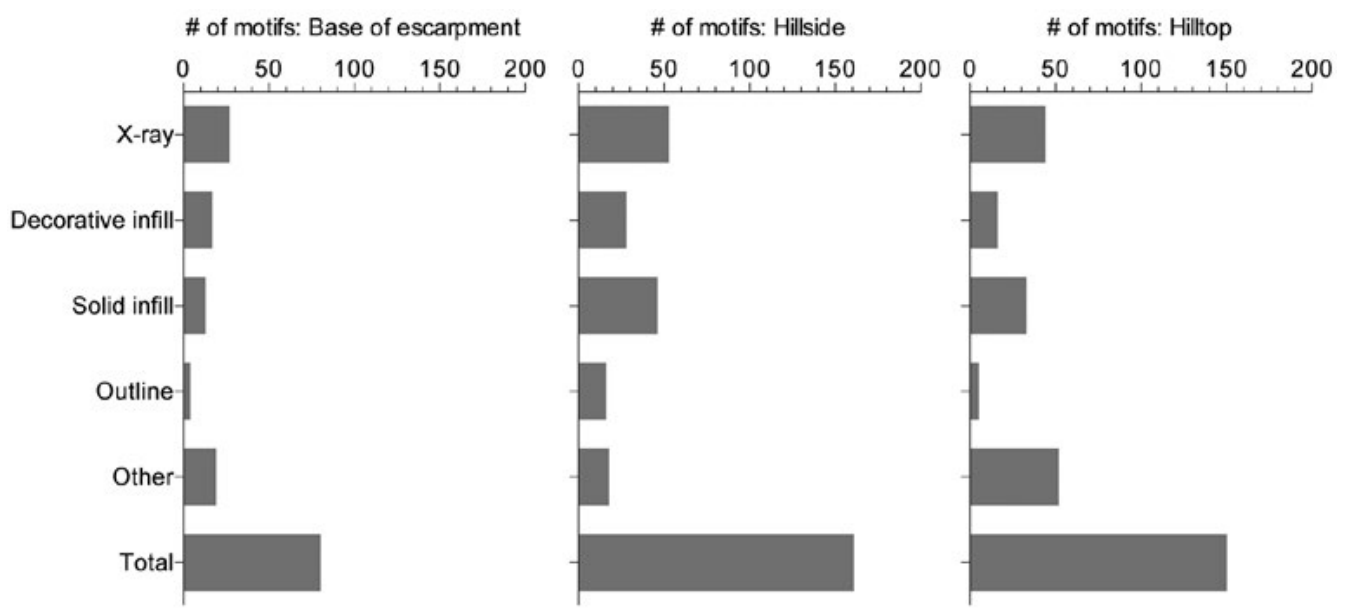

Figure 2.9 Painting manner for fish, by topographic zone.

Source: Jerome Mialanes.

\section{Anthropomorphs}

At Wulk Lagoon, anthropomorphs include a range of shapes and associated items of material culture (see Figure 2.10). Human or human-like figures occur in over 80 per cent of art sites. The majority are males with spears. Many have headdresses and spearthrowers, and a range of spear types is depicted. There is greater diversity in types of weapons than there is in armlets, neckbands, aprons, fans and bags. There are also high numbers of scenes where human figures are engaged in what appear to be ceremony (10.3 per cent), fighting (11.6 per cent) and hunting (23.3 per cent); most of these are in what are thought to be late Holocene styles. Some scenes are in the Northern Running Figure style.

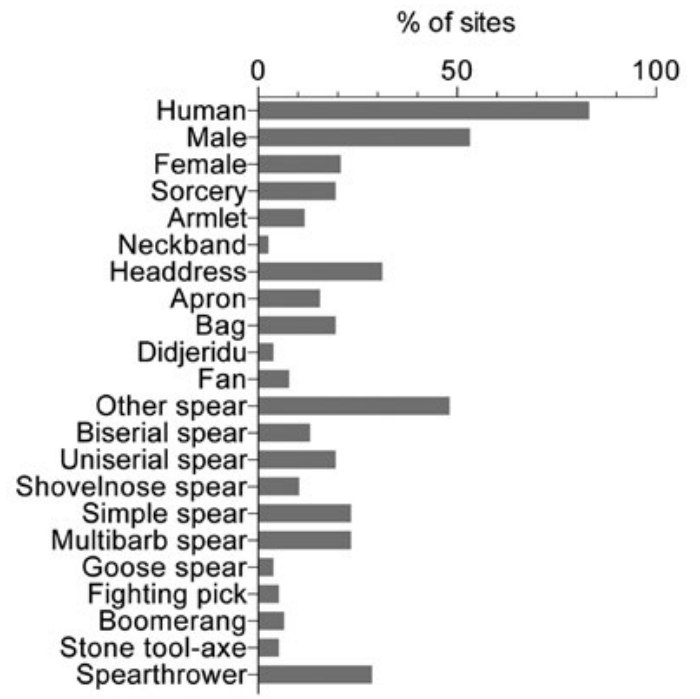

Figure 2.10 Proportion of sites with paintings of anthropomorphs and items of material culture ( $\mathrm{n}=77$ sites).

Source: Jerome Mialanes.

\section{The Minjnymirnjdawabu sites: MN01, MN05 and MN12}

A detailed study was undertaken of 65 rock art panels at three of the Minjnymirnjdawabu sites (MN01, MN05 and MN12). Here the art is again mainly in late Holocene styles. Pigment colours are diverse, many consisting of hues of red, white, orange or yellow (Figure 2.11). Many paintings are in two or more colours, and much pigment was used. Anthropomorphs and fish motifs are again common. Fish were painted in three distinctive patterns: solid infill, outline and X-ray (Figure 2.12). 
The size of art panels appears to have largely been affected by local geology, although there is a continuum in the area of the wall surface selected for painting (Figure 2.13). Figure 2.14 indicates moderate levels of damage on the 65 art panels.

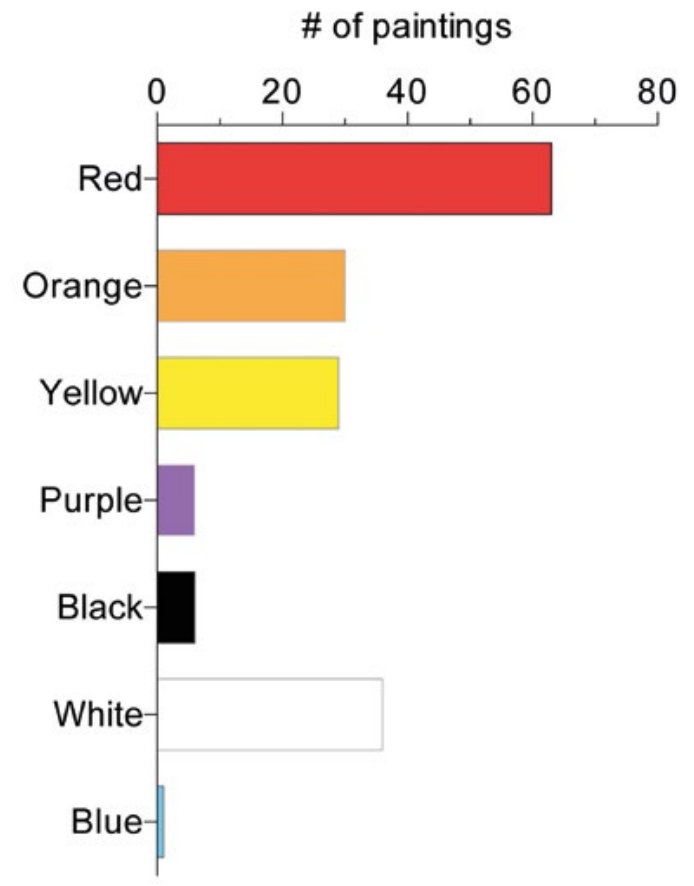

Figure 2.11 Number of paintings by colour, sites MN01, MN05 and MN12.

Source: Jerome Mialanes.

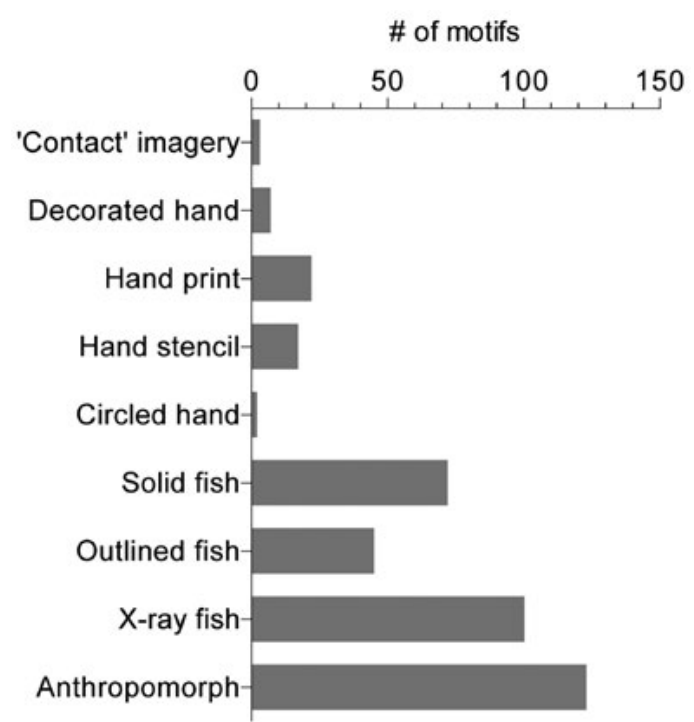

Figure 2.12 Number of artworks by motif type, sites MN01, MN05 and MN12.

Source: Jerome Mialanes.

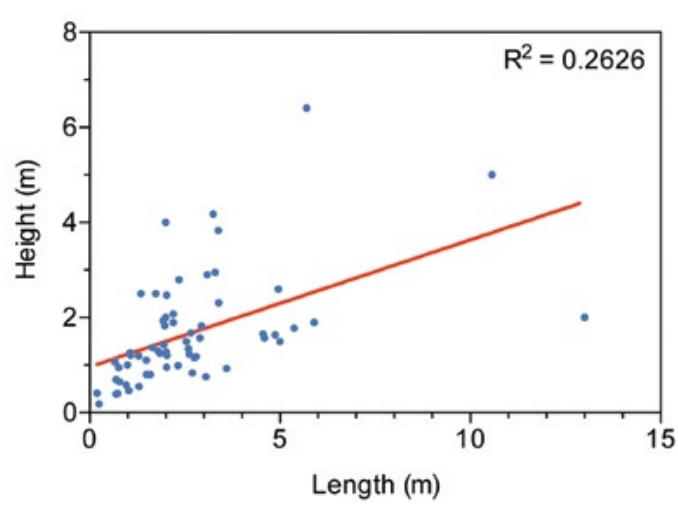

Figure 2.13 Distribution of panel sizes, sites MN01, MN05 and MN12 ( $n=65$ panels). Source: Jerome Mialanes.

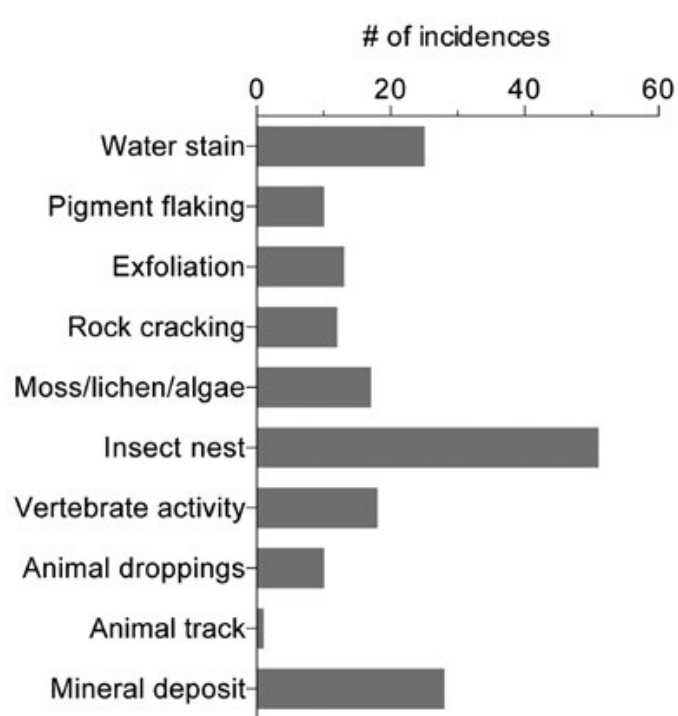

Figure 2.14 Frequency of impacts on rock art across 65 rock art panels, sites MN01, MN05 and MN12.

Source: Jerome Mialanes. 


\section{Archaeological excavation: MN05}

MN05 was selected for excavation because it appeared to have the best potential for datable occupational deposits (Figure 2.15). This is a rockshelter with a large overhang, $8 \mathrm{~m} \mathrm{long}$, $5 \mathrm{~m}$ wide, with an average height of $2.75 \mathrm{~m}$ from floor to ceiling. The ceiling and walls have a number of panels with multiple layers of art, including an impressive array of $\mathrm{X}$-ray paintings of local freshwater fish. The site also contains the famous 'blue' contact painting of a sailing ship. Grinding hollows and surfaces are abundant, attesting to much occupation.

Three $1 \times 1 \mathrm{~m}$ test pits were excavated: one against the wall (Test Pit B), one just outside the dripline (Test Pit A) and one outside the overhang to test the depth of sediment drop-off (Test Pit C). Test Pit A quickly bottomed out on a slab of sandstone. Test Pits B and C were deeper, providing information on occupation beginning shortly after $1000 \mathrm{cal} \mathrm{BP}$ (Table 2.3).

Table 2.3 Radiocarbon dates on charcoal from Test Pits B and C, MN05.

\begin{tabular}{|l|c|c|c|c|c|c|c|}
\hline Laboratory code & $\begin{array}{c}\text { Test } \\
\text { Pit }\end{array}$ & Excavation unit & $\begin{array}{c}\text { Depth } \\
\text { (cm) }\end{array}$ & $\begin{array}{c}{ }^{13} \text { ( per } \\
\text { mil }\end{array}$ & $\begin{array}{c}\text { \% modern } \\
\text { carbon }\end{array}$ & $\begin{array}{c}\text { Radiocarbon } \\
\text { date (BP) }\end{array}$ & $\begin{array}{c}\text { Calibrated age } \\
\text { (95.4\% probability) } \\
\text { (cal BP) }\end{array}$ \\
\hline D-AMS 007849 & B & 21 & 47 & -24.2 & $97.95 \pm 0.25$ & $166 \pm 21$ & $165-225$ \\
\hline D-AMS 007850 & C & 23 & 95 & -24.5 & $88.97 \pm 0.24$ & $939 \pm 22$ & $795-950$ \\
\hline
\end{tabular}

Source: OxCal v4.2.3 Bronk Ramsey (2009); IntCal13 atmospheric curve (Reimer et al. 2013).

The deposits contain post-contact objects such as glass flakes and fragments, ceramic sherds, buttons, bullets, metal fragments and glass beads. Stone artefacts are mostly quartz flakes and quartzite. There are many red, yellow, orange and white 'ochre' fragments. A number of these are haematite crayons with striations clearly evident. Five beeswax fragments and a nodule of Reckitt's Blue were recovered from Test Pit B. Faunal remains include barramundi (Lates calcarifer) and catfish (Arius leptaspis) otoliths, freshwater turtle bone fragments, varanid (monitor lizard) teeth and freshwater bivalve shells (Mytilus sp.); highly fragmented, non-diagnostic burnt bone is abundant. There is evidence of bioturbation of sediments by macropods, introduced feral animals and human hearth-building.

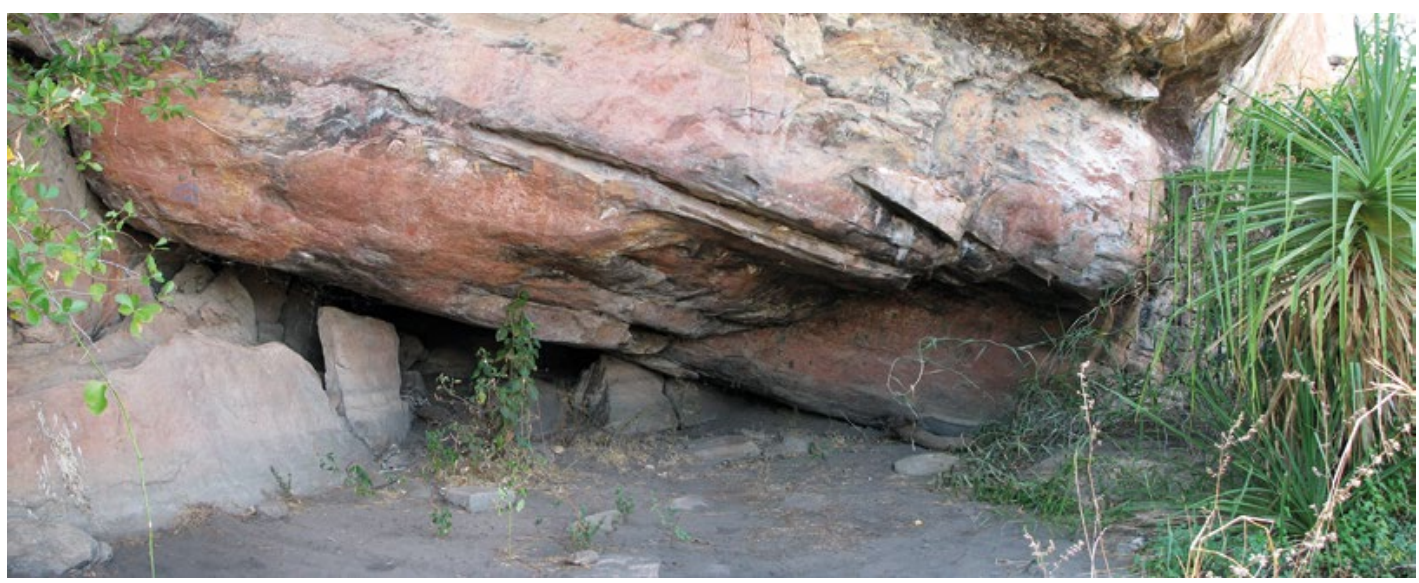

Figure 2.15 Site MN05.

Source: Photograph by Daryl Wesley.

Excavation and ground penetrating radar (GPR) surveys indicate significant build-up of sands at the base of the Wulk Lagoon sandstone escarpment. Nott (2003) provides estimates of up to $6 \mathrm{~m}$ of accumulated sands from the plateau onto the coastal plains, dating back from Pleistocene times. In Test Pit C outside the MN05 shelter, $1 \mathrm{~m}$ of sand has accumulated in 1000 years. 
Excavations at MN05 and nearby Birriwilk (Shine et al. 2013; see Figure 1.1) show that cultural deposits have limited depth confined to the last 5000 years at the edge of the Wulk Lagoon sandstone outlier. Here any evidence of early Holocene or Pleistocene occupation would be buried under several metres of aggraded sand and flood deposits.

\section{Discussion}

Figure 2.16 shows two things for Wulk Lagoon's rock art by temporal phase: 1) the proportion of total number of rock art styles; and 2) the proportion of total number of motifs (of any style) (see Figure 2.2 for details of each phase). There are few sites with Early Phase styles (those that are thought to be older than c. $8000 \mathrm{BP}$ ), and few motifs within those sites that do have them. Many (58 per cent) of the sites have Middle Phase styles (c. 8000 to 3000 BP), but these contain a moderate proportion of motifs (only 25 per cent of the overall rock art assemblage). There are a moderate number (33 per cent) of sites with Late Phase (c. 3000 BP to present) styles, but these contain the majority of motifs (accounting for 70 per cent of the total assemblage). Most of the art in the 18 sites with more than 100 images (which together account for 90 per cent of Wulk Lagoon's rock art) are in late Holocene styles. At Wulk Lagoon, therefore, during the late Holocene, rock art becomes very abundant in a moderate number of focal sites; it is less evenly distributed across the landscape than previously.

Paintings of fish are fairly evenly distributed between the Middle and Late Phases: 45.5 per cent are in styles of the Middle Phase, 54.5 per cent in those of the Late Phase. This is consistent with a heightened importance of fish following risen sea levels, coastal infill and the development of swamps and waterways on the floodplains after c. 6000 BP. At sites MN01, MN05 and MN12, most paintings are of fish (55.5 per cent) and anthropomorphs (31.5 per cent), and of these most are in Late Phase (i.e. late Holocene) styles; 71 per cent of rock art scenes at Wulk Lagoon (i.e. ceremony, fighting and hunting) are also in Late Phase styles (all others are of the Middle Phase). Here, there is clearly a proliferation of rock art in the Middle and Late Phases when fish, anthropomorphs and scene depictions predominate.

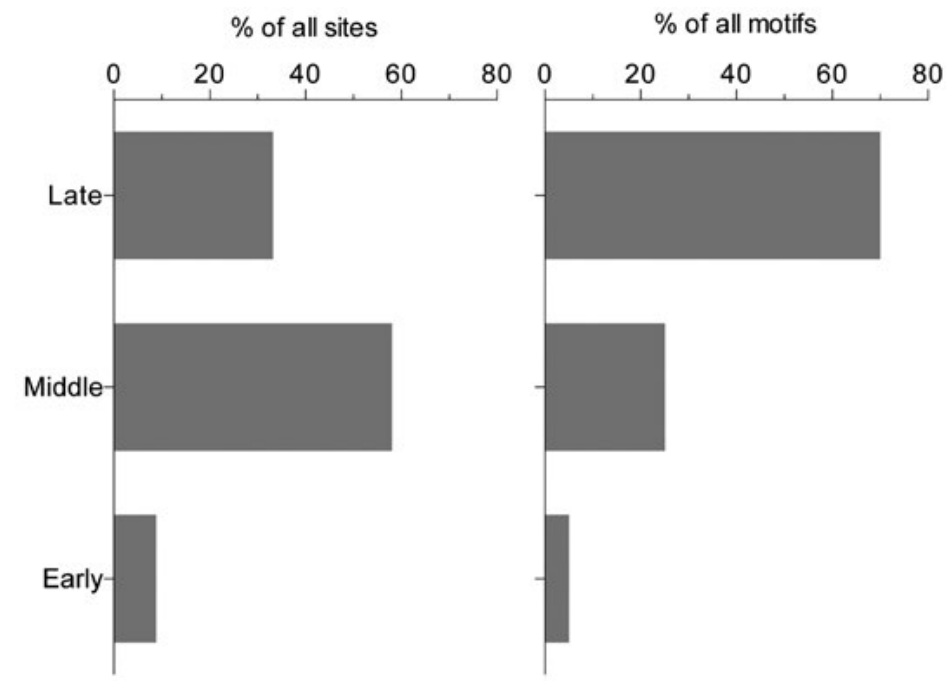

Figure 2.16 Relative frequency of rock art sites and motifs by temporal phase (number of sites $=77$; estimated number of motifs $=13,000$ ).

Source: Jerome Mialanes. 
Macropods occur in 36.3 per cent of Wulk Lagoon sites, often in Large Naturalistic or Large Fauna styles. An $\mathrm{R}^{2}$ value of 0.4846 indicates no preferential co-occurrence of zoomorphs with anthropomorphs. This suggests that in many cases sites were selected to paint zoomorphs or anthropomorphs, but not both.

Much of Wulk Lagoon's rock art is found at the top of the sandstone outlier, with fewer sites along the base of the escarpment (Figure 2.17). Figures 2.18 and 2.19 show the number of rock art sites and art styles that occur, by geographic zone for each phase (see caption to Figure 2.19 for further description on calculation of number of art styles represented). During the Early and Middle Phases, the art is most abundant on the hillsides; however, during the Late Phase, it is fairly evenly distributed across all three zones.

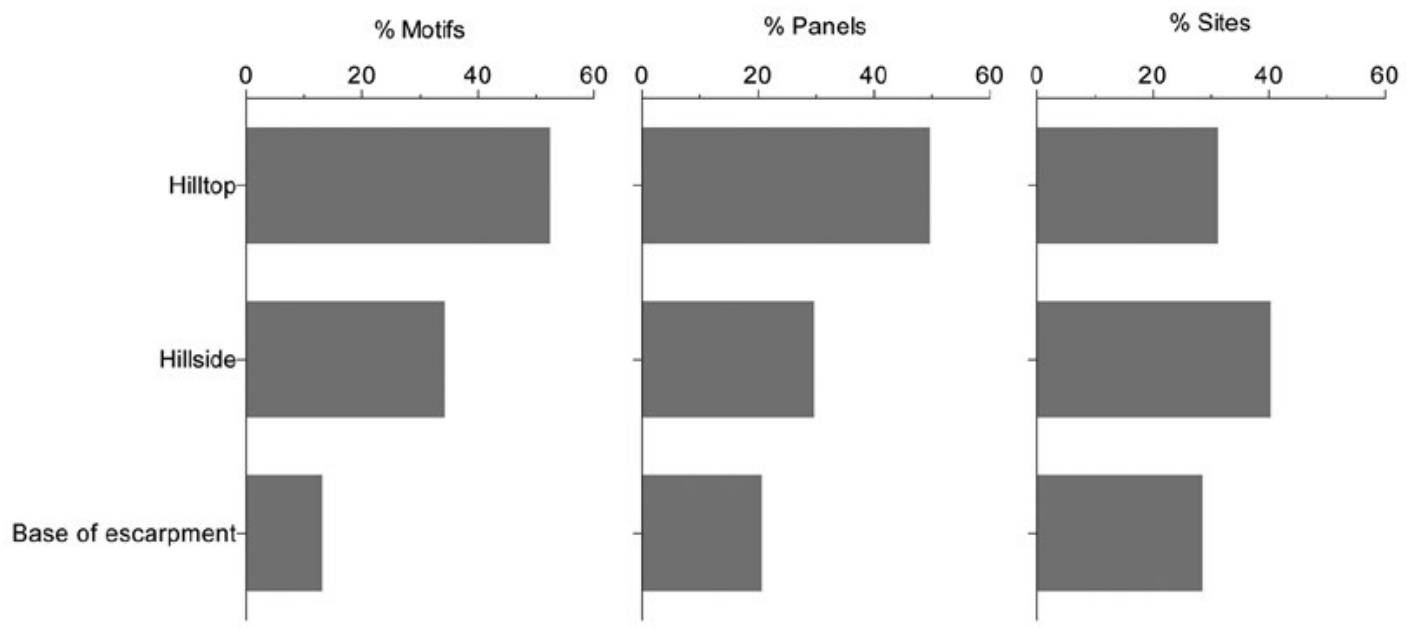

Figure 2.17 Proportion of motifs, panels and sites by topographic zone (number of motifs $=13,000$; number of panels $=459$; number of sites $=77$ ).

Source: Jerome Mialanes.

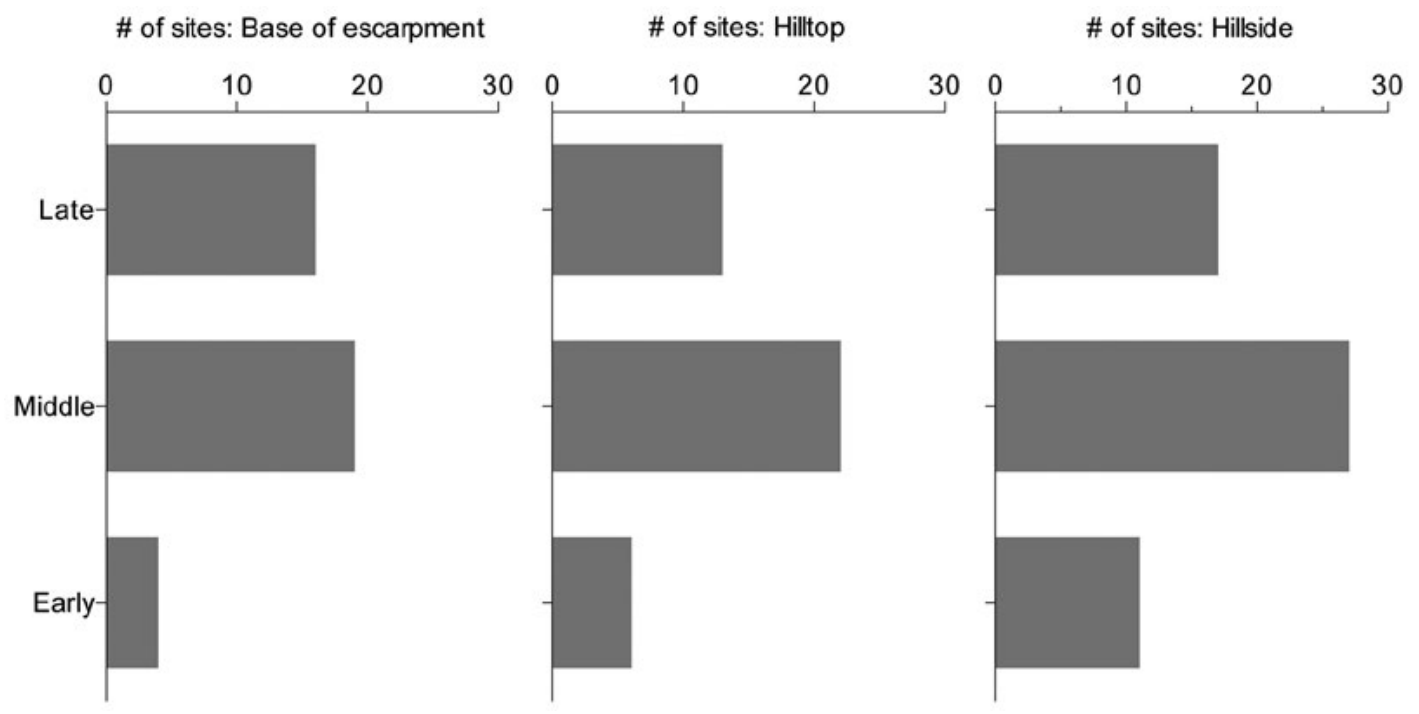

Figure 2.18 Number of rock art sites by phase and topographic zone.

Source: Jerome Mialanes. 

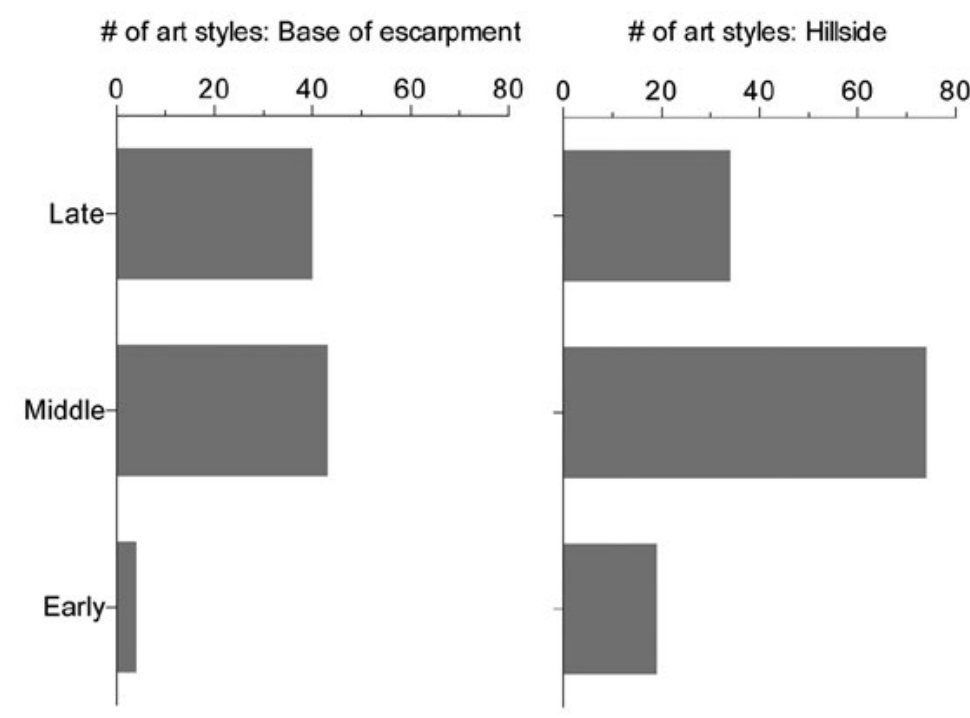

\# of art styles: Hilltop

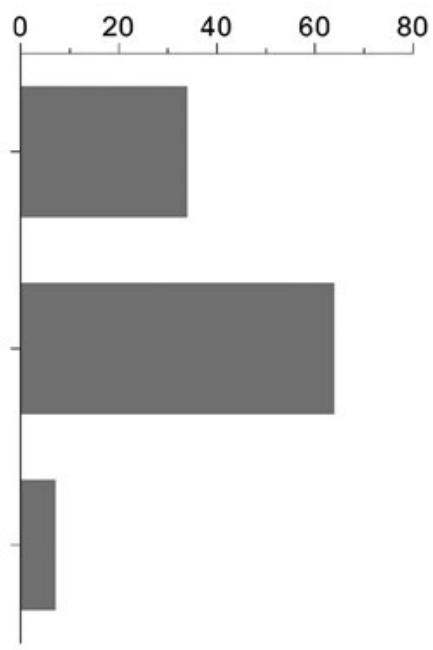

Figure 2.19 Sum of the number of different art styles represented per site, by phase and topographic zone.

(e.g. if there are two Late Phase sites on a hillside, one site with five paintings of one style and the other with three paintings of another style, then that site will have two different art styles represented for that phase; to work out how many art styles are represented in the hillside environment, all such Late Phase site values are summed).

Source: Jerome Mialanes.

These results suggest that during the late Holocene, pretty much all topographic zones of the Wulk Lagoon sandstone outlier were inscribed with rock art. Taçon and Chippindale (1994), Taçon and Brockwell (1995) and Hiscock (1999) have argued that the late Holocene saw rich resource supplies on the floodplains, resulting in population growth and increasing regionalism of clan estates: social organisation and land tenure systems shifted as clan estates with geographically based totemic associations changed. This is consistent with the shifting distributions and peak densities of rock art seen during the late Holocene at Wulk Lagoon. Here small clan estates with focalised occupation used sites intensively into the ethnographic period, as evident by the diverse and abundant rock art of the late Holocene. We suggest that this is evidence for lower levels of residential mobility and greater rock art production than previously. This happened at a time of increasing precipitation and strengthening of the IASM c. 1000 years ago, when the East Alligator floodplain developed deep lagoons, shallow lakes and productive Eleocharis and Melaleuca swamps. Across much of Arnhem Land, X-ray art and the Complete Figure Complex flourished at this time, and there was a notable increase in the movement of exotic raw materials for the production of stone artefacts (e.g. Shine et al. 2013). The rock art and buried archaeological deposits of that time both seem to signal the onset of the kinds of cultural practices encountered at the time of European contact.

In support of this interpretation, Wulk Lagoon boasts a wide variety of rock paintings we might consider as scenes $(n=35)$ (Taçon 1994). May and Domingo Sanz (2010:41) discuss the significance of rock art scenes as modes of encoding socio-cultural practices. At Wulk Lagoon, late Holocene scenes have long been a focus of research (e.g. Chaloupka 1993; Jelinek 1986; Mountford 1956; Moyle 1981), especially those depicting the playing of didjeridus, prominent in at least eight scenes. The didjeridu is considered by Moyle (1981) to be a late Holocene musical development in Arnhem Land, because of the rock art styles it is associated with.

Although scenes are also found during earlier phases, their proliferation and increased variability during the late Holocene may be a reflection of the increasing density of local populations in the Alligator Rivers region (May and Domingo Sanz 2010). In contrast to the early battle scenes 
reported by Taçon and Chippindale (1994), at Wulk Lagoon those of the late Holocene generally involve fewer personages. Scenes depicting groups of $>10$ males engaged in either actual or ritual combat, or hunting, express individual engagements in social events (see Figure 2.20).

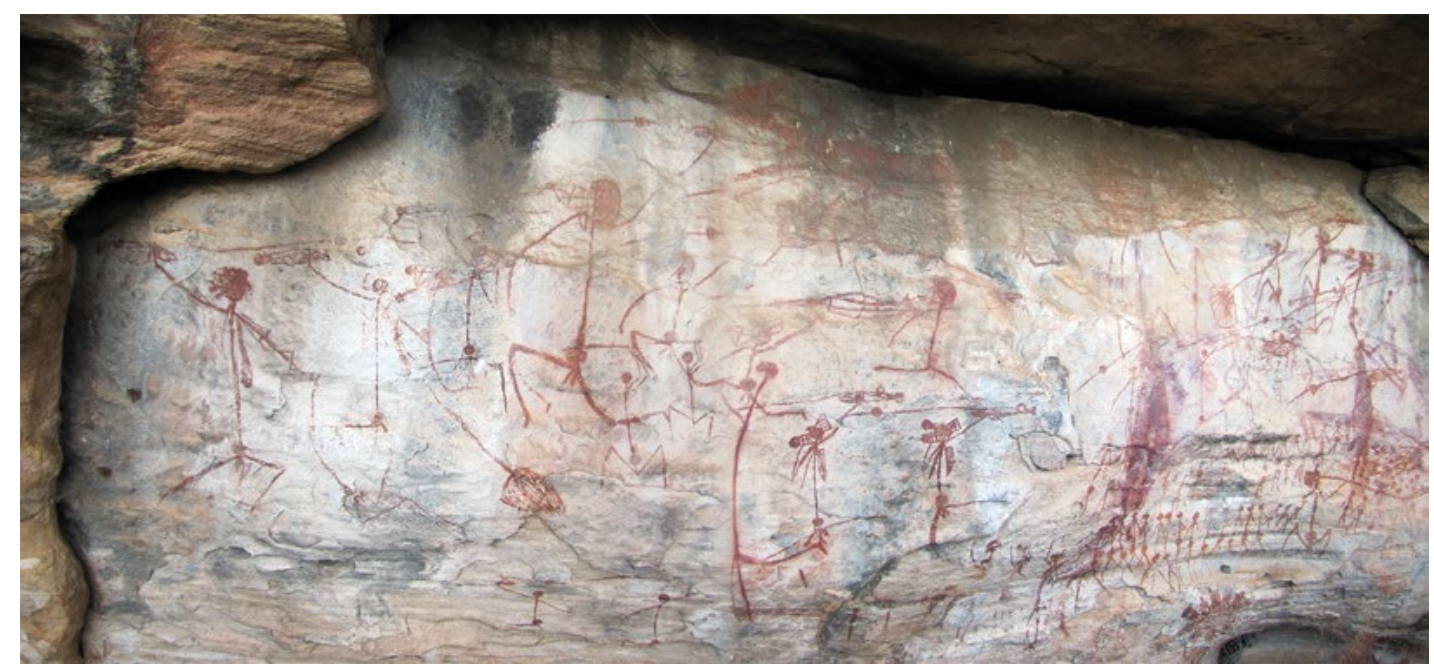

Figure 2.20 Example of complex late Holocene art scene, Wulk Lagoon site RLL004.

Source: Photograph by Paul Brugman.

That people and fish predominate in the rock art of the late Holocene might be linked to a number of factors. The emergence of freshwater wetlands c. 1500 years ago provisioned people with an enormous diversity and abundance of resources, driving population numbers and densities (see Hiscock 1999; Jones 1985). An intensifying IASM after c. 1000 years ago saw greater precipitation and major flooding events that would have significantly impacted on the development of freshwater systems in the Wulk Lagoon area (Denniston et al. 2013; Sandercock and Wywroll 2005; Wasson et al. 2010). Whether regional population densities were a result of actual population growth or a reorganisation of existing groups from the broader region, mid to late Holocene rock art production signal increasing occupation intensities in the vicinity of Wulk Lagoon. With a greater population exploiting newly developed wetland resources came greater levels of rock art production, increased rates of deposition of food refuse within sites and increased stone artefact production (see also Allen and Barton 1989; Jones 1985; Schrire 1982; Shine et al. 2013).

In Arnhem Land, the proliferation of rock art during the late Holocene has been noted in a number of previous studies (e.g. Chaloupka 1993; Taçon 1989a, 1989b). However, its significance is often ignored or sidelined in narratives of the past (Hiscock 1999). Alongside the development of new stone tool technologies, perhaps to manage risks or exploit emerging environments, the proliferation of late Holocene rock art at Wulk Lagoon is an integral expression of the reorganisation of human populations in the Alligator Rivers region.

\section{Acknowledgements}

We thank Nagajok Nayingull, the Nayingull family and Manilakarr Traditional Owners for their support, guidance and enthusiasm in the field. Fieldwork by Daryl Wesley (DE170101447) was undertaken with the assistance of a George Chaloupka Fellowship from the Museum and Art Gallery of the Northern Territory, kindly funded by ERA Rio Tinto. We also thank Sue O'Connor for assisting in the field via ARC Linkage project LP0882985, Tony Barham (The Australian National University, ANU) for helping organise the ARCH8002 field class, the

\section{terra australis 47}


Masters of Archaeological Science (ARCH8002) participants for field assistance, Jack Fenner and Bruce Brown for GPR surveys, Christian Reepmeyer, Paul Brugman, Noel Hildago-Tan, the Bushfires Council Northern Territory, the Commonwealth Department of Sustainability, Environment Heritage and Water, the Office of the Supervising Scientist, the Northern Land Council for research approvals, the North Australia Research Unit (ANU) for providing a base of operations for the fieldwork, Eva Purvis and Anna Yeo for assisting with anthropological matters and Jerome Mialanes (Monash University) for drafting most of the figures.

\section{References}

Allen, H. and G. Barton 1989. Ngarradj Warde Djobkeng: White Cockatoo Dreaming and the Prehistory of Kakadu, Northern Territory, Australia. Oceania Monograph 37. Oceania Publications, Sydney.

Andrefsky, W. 2005. Lithics: Macroscopic Approaches to Analysis. Cambridge University Press, Cambridge. doi.org/10.1017/CBO9780511810244

Andrefsky, W. 2009. The analysis of stone tool procurement, production, and maintenance. Journal of Archaeological Research 17(1):65-103. doi.org/10.1007/s10814-008-9026-2

Attenbrow, V., G. Robertson and P. Hiscock 2009. The changing abundance of backed artefacts in southeastern Australia: A response to Holocene climate change? Journal of Archaeological Science 36:27652770. doi.org/10.1016/j.jas.2009.08.018

Baxter, M.J. 2001. Methodological issues in the study of assemblage diversity. American Antiquity 66(4):715-725. doi.org/10.2307/2694184

Bednarik, R.G. 2012. The use of weathering indices in rock art science and archaeology. Rock Art Research 29(1):59-84.

Bednarik, R.G. 2014a. Mud-wasp nests and rock art. Rock Art Research 31(2):225-231.

Bednarik, R.G. 2014b. Pleistocene paleoart of Australia. Arts 3(1):156-174. doi.org/10.3390/ arts3010156

Bird, M.I., C.S.M. Turney, L.K. Fifield, R. Jones, L.K. Ayliffe, A. Palmer, R. Cresswell and S. Robertson 2002. Radiocarbon analysis of the early archaeological site of Nauwalabila I, Arnhem Land, Australia: Implications for sample suitability and stratigraphic integrity. Quaternary Science Reviews 21:1061-1075. doi.org/10.1016/S0277-3791(01)00058-0

Bourke, P. 2000. Late Holocene Indigenous Economies of the Tropical Australian Coast: An Archaeological Study of the Darwin Region. Unpublished PhD thesis, Northern Territory University, Darwin.

Bourke, P., S. Brockwell, P. Faulkner and B. Meehan 2007. Climate variability in the mid to late Holocene Arnhem Land region, north Australia: Archaeological archives of environmental and cultural change. Archaeology in Oceania 42:91-101. doi.org/10.1002/j.1834-4453.2007.tb00022.x

Brandl, E.J. 1970. Arnhem Land X-ray: Part One. Unpublished report. Australian Institute of Aboriginal Studies, Canberra.

Brandl, E.J. 1980. Some notes on faunal identification and Arnhem Land rock paintings. Australian Institute of Aboriginal Studies (AIAS) Newsletter 14:6-13.

Brockwell, C.J. 1989. Archaeological Investigations of the Kakadu Wetlands, Northern Australia. Unpublished MA thesis. The Australian National University, Canberra. 
Brockwell, S. 1996. Open sites of the South Alligator River wetland, Kakadu. In P. Veth and P. Hiscock (eds), Archaeology of Northern Australia, pp. 90-105. Tempus No. 4. Anthropology Museum, University of Queensland, St Lucia.

Brockwell, S., P. Bourke, A. Clarke, C. Crassweller, P. Faulkner, B. Meehan, S. O'Connor, R. Sim and D. Wesley 2011. Holocene settlement of the northern coastal plains, Northern Territory, Australia. The Beagle: Records of the Museums and Art Galleries of the Northern Territory 27:1-22.

Brockwell, S., A. Clarke and R. Levitus 2001. Seasonal movement in the prehistoric human ecology of the Alligator Rivers region, north Australia. In A. Anderson, I. Lilley and S. O'Connor (eds), Histories of Old Ages: Essays in honour of Rhys Jones, pp. 361-380. Pandanus Books, Canberra.

Brockwell, S., P. Faulkner, P. Bourke, A. Clarke, C. Crassweller, D. Guse, B. Meehan and R. Sim 2009. Radiocarbon dates from the Top End: A cultural chronology for the Northern Territory coastal plains. Australian Aboriginal Studies (1):54-76.

Bronk Ramsey, C. 2009. Bayesian analysis of radiocarbon dates. Radiocarbon 51(1):337-360. doi.org/10.1017/S0033822200033865

Bühler, A., T. Barrow and C.P. Mountford 1965. Oceania and Australia: The Art of the South Seas. Holle and Co., Germany.

Chaloupka, G. 1977. Aspects of the chronology and schematisation of two prehistoric sites on the Arnhem Land plateau. In P.J. Ucko (ed.), Form in Indigenous Art: Schematisation in the Art of Aboriginal Australia and Prehistoric Europe, pp. 243-259. Australian Institute of Aboriginal Studies, Canberra.

Chaloupka G. 1984. From Palaeoart to Casual Paintings: The Chronological Sequence of Arnhem Land Plateau Rock Art. Monograph Series 1. Northern Territory Museum of Arts and Sciences, Darwin.

Chaloupka, G. 1985. Chronological sequence of Arnhem Land plateau rock art. In R. Jones (ed.), Archaeological Research in Kakadu National Park, pp. 2692-80. Special Publication 13. Australian National Parks and Wildlife Service, Canberra.

Chaloupka, G. 1993. Journey in Time: The World's Longest Continuing Art Tradition. Reed, Chatswood.

Chappell, J. 1988. Geomorphologic dynamics and evolution of tidal river and floodplain systems in northern Australia. In D. Wade-Marshall and P. Loveday (eds), Floodplains Research, Northern Australia: Progress and Prospects Volume 2, pp. 34-57. North Australia Research Unit, The Australian National University, Darwin.

Chappell, J. 1993. Contrasting Holocene sedimentary geologies of lower Daly River, northern Australia, and lower Sepik-Ramu, Papua New Guinea. Sedimentary Geology 83:339-358. doi.org/10.1016/ 0037-0738(93)90020-6

Chappell, J. and J. Grindrod 1985. Pollen analysis: Key to past mangrove communities and successional changes in north Australian coastal environments. In K.N. Bardsley, J.D.S. Davie and C.D. Woodroffe (eds), Coasts and Tidal Wetlands of the Australian Monsoon Region, pp. 225-238. Mangrove Monograph No. 1. North Australia Research Unit, The Australian National University, Darwin.

Chippindale, C. and P.S.C. Taçon 1993. Two old painted panels from Kakadu: Variation and sequence in Arnhem Land rock art. Time and Space: Dating and Spatial Considerations in Rock Art Research, pp. 32-56. Australian Rock Art Research Association, Melbourne.

Chippindale, C. and P.S.C. Taçon 1998. The many ways of dating Arnhem Land rock art, north Australia. In C. Chippindale and P.S.C. Taçon (eds), The Archaeology of Rock Art, pp. 91-111. Cambridge University Press, Cambridge. 
Clark, M. and S.K. May (eds), 2013. Macassan History and Heritage: Journeys, Encounters and Influences. ANU E Press, Canberra.

Clark, R.L. and J.C. Guppy 1988. A transition from mangrove forest to freshwater wetland in the monsoon tropics of Australia. Journal of Biogeography 15(4):665-684. doi.org/10.2307/2845444

Clarkson, C. 2002. An index of invasiveness for the measurement of unifacial and bifacial retouch: A theoretical, experimental and archaeological verification. Journal of Archaeological Science 1:65-75. doi.org/10.1006/jasc.2001.0702

Clarkson, C. 2007. Lithics in the Land of the Lightning Brothers: The Archaeology of Wardaman Country, Northern Territory. Terra Australis 25. ANU E Press, Canberra.

Clarkson, C., Z. Jacobs, B. Marwick, R. Fullagar, L. Wallis, M. Smith, R.G. Roberts, E. Hayes, K. Lowe, X. Carah, S.A. Florin, J. McNeil, D. Cox, L. J. Arnold, Q. Hua, J. Huntley, H.E.A. Brand, T. Manne, A. Fairbairn, J. Shulmeister, L. Lyle, M. Salinas, M. Page, K. Connell, G. Park, K. Norman, T. Murphy and C. Pardoe 2017. Human occupation of Australia by 65,000 years. Nature 547(7663): 306-310 doi.org/10.1038/nature22968

David, B. and H. Lourandos 1998. Rock art and socio-demography in northeastern Australian prehistory. World Archaeology 30(2):193-219. doi.org/10.1080/00438243.1998.9980407

David, B., B. Barker, F. Petchey, J.-J. Delannoy, J.-M. Geneste, C. Rowe and R. Whear 2012. A 28,000 year old excavated painted rock from Nawarla Gabarnmang, northern Australia. Journal of Archaeological Science 40(5):2493-2501. doi.org/10.1016/j.jas.2012.08.015

Delannoy, J.-J., B. David, J.-M. Geneste, M. Katherine, B. Barker, R.L. Whear and R.G. Gunn 2013. The social construction of caves and rockshelters: Chauvet Cave (France) and Nawarla Gabarnmang (Australia). Antiquity 87(335):12-29. doi.org/10.1017/S0003598X00048596

Denniston, R.F., K. Wyrwoll, V.J. Polyak, J.R. Brown, Y. Asmerom, A.D. Wanamaker, Z. La Pointe, R. Ellerbroek, M. Barthelmes, D. Cleary, J. Cugley, D. Woods and W.F. Humphreys 2013. A stalagmite record of Holocene Indonesian-Australian summer monsoon variability from the Australian tropics. Quaternary Science Reviews 78:155-168. doi.org/10.1016/j.quascirev.2013.08.004

Duggan, K. 1994. Erosion and sediment yields in the Kakadu region of northern Australia. In L.J. Olive, R.J. Loughran and J.A. Kesby (eds), Variability in Stream Erosion and Sediment Transport (Proceedings of the Canberra Symposium, December 1994), pp. 373-383. International Association of Hydrological Sciences Publication 224, Oxfordshire.

East, T.J., R.F. Cull, A.S. Murray, A. Johnston, B. Noller, R.J. Wasson, I.R. Willett, G. Pickup and R.F. Warner 1987a. Late Quaternary evolution of the Magela Creek backwater plain. In Alligator Rivers Research Institute Annual Research Summary 1986-7, pp. 29-36. Australian Government Publishing Service, Canberra.

East, T.J., A.S. Murray, G.C. Nanson and R.L. Clark 1987b. Late Quaternary evolution of the Magela Creek sandbed channels and floodplain. In Alligator Rivers Research Institute Annual Research Summary 1986-7, pp. 22-29. Australian Government Publishing Service, Canberra.

Edwards, R. 1979. Australian Aboriginal Art: The Art of the Alligator Rivers Region, Northern Territory. Australian Institute of Aboriginal Studies, Canberra.

Faulkner, P. 2009. Focused, intense and long-term: Evidence for granular ark (Anadara granosa) exploitation from late Holocene shell mounds of Blue Mud Bay, northern Australia. Journal of Archaeological Science 36(3):821-834. doi.org/10.1016/j.jas.2008.11.005 
Faulkner, P. 2011. Late Holocene mollusc exploitation and changing near-shore environments: A case study from the coastal margin of Blue Mud Bay, northern Australia. Environmental Archaeology 16(2):137-150. doi.org/10.1179/174963111X13110803260976

Geneste, J.-M., B. David, H. Plisson, C. Clarkson, J.-J. Delannoy, F. Petchey and R. Whear 2010. Earliest evidence for ground-edge axes: 35,400 4410 cal BP from Jawoyn country, Arnhem Land. Australian Archaeology 71:66-69. doi.org/10.1080/03122417.2010.11689385

Geneste, J.-M., B. David, H. Plisson, J.-J. Delannoy and F. Petchey 2012. The origins of ground-edge axes: New findings from Nawarla Gabarnmang, Arnhem Land (Australia) and global implications for the evolution of fully modern humans. Cambridge Archaeological Journal 22(1):1-17. doi.org/ $10.1017 /$ S0959774312000017

Gregory, R.L. 1998. Aboriginal settlement patterns in the Ord-Victoria River region. Unpublished PhD thesis. Northern Territory University, Darwin.

Grindrod, J. 1988. Holocene Mangrove History of the South Alligator River Estuary, Northern Territory, Australia. Unpublished PhD thesis. The Australian National University, Canberra.

Gunn, R.G. 1992. Mikinj: Rock art, myth and place - sites of significance to Jacob Nayinggul. Unpublished report to the Australian Institute of Aboriginal and Torres Strait Islander Studies. AIATSIS, Canberra.

Gunn, R.G. and R.L. Whear 2007a. Dynamic sketches: 6000+ year old dry-pigment drawings from Arnhem Land. Archaeology in Oceania 42(1):22-28. doi.org/10.1002/j.1834-4453.2007.tb00011.x

Gunn, R.G. and R.L. Whear 2007b. The Jawoyn rock art and heritage project. Rock Art Research 24(1):5-20.

Gunn, R.G., C. Ogleby, D. Lee and R. Whear 2010a. A method to visually rationalise superimposed pigment motifs. Rock Art Research 27(2):131-136.

Gunn, R.G., R.L. Whear and L.C. Douglas 2010b. A dingo burial from the Arnhem Land plateau. Australian Archaeology 71:11-16. doi.org/10.1080/03122417.2010.11689380

Gunn, R.G., L.C. Douglas and R.L. Whear 2011. What bird is that? Identifying a probable painting of Genyornis newtoni in western Arnhem Land. Australian Archaeology 73:1-12.

Gunn, R.G., R.L. Whear and L.C. Douglas 2012. Dating the present at Nawarla Gabarnmang: Time and function in the art of a major Jawoyn rock art and occupation site in western Arnhem Land. Australian Archaeology 75:55-65. doi.org/10.1080/03122417.2012.11681950

Guse, D.L 1992. Predictive models of prehistoric settlement and subsistence patterns for the South Alligator and Mary River wetlands, Northern Territory. Unpublished BA (Honours) thesis. Department of Anthropology, Northern Territory University, Darwin.

Guse, D.L. 2006. Our home our country: A case study of law, land, and Indigenous cultural heritage in the Northern Territory, Australia. Unpublished Masters of Aboriginal and Torres Strait Islander Studies, Faculty for Aboriginal and Torres Strait Islander Studies, Charles Darwin University, Darwin.

Hiscock, P. 1999. Holocene coastal occupation of western Arnhem Land. In J. Hall and I.J. McNiven (eds), Australian Coastal Archaeology, pp. 91-103. Department of Archaeology and Natural History, The Australian National University, Canberra. 
Hiscock, P. 2002. Pattern and context in the Holocene proliferation of backed artefacts in Australia. In R.G. Elston and S.L. Kuhn (eds), Thinking Small: Global Perspectives on Microlithization, pp. 163-177. Archaeological Papers of the American Anthropological Association 12(1):163-177.

Hiscock, P. 2008. Archaeology of Ancient Australia. Routledge, London. doi.org/10.4324/9780203448359

Hiscock, P. 2011. Changing perspectives in Australian archaeology, Part VI: Point production at Jimede 2, western Arnhem Land. Technical Reports of the Australian Museum 23(6):73-82. doi.org/10.3853/j.1835-4211.23.2011.1571

Hiscock, P. and V. Attenbrow 1998. Early Holocene backed artefacts from Australia. Archaeology in Oceania 33(2):49-62. doi.org/10.1002/j.1834-4453.1998.tb00404.x

Hiscock, P. and V. Attenbrow 2005. Reduction continuums and tool use. In C. Clarkson and L. Lamb (eds), Lithics 'Down Under': Australian Perspectives on Lithic Reduction, Use and Classification, pp. 43-55. Archaeopress, Oxford.

Hiscock, P., F. Mowat and D. Guse 1992. Settlement patterns in the Kakadu wetlands: Initial data on site size and shape. Australian Aboriginal Studies 2:84-89.

Hope, G., P.J. Hughes and J. Russell-Smith 1985. Geomorphological fieldwork and the evolution of the landscape of Kakadu National Park. In R. Jones (ed.), Archaeological Research in Kakadu National Park, pp. 229-240. Special Publication 13. Australian National Parks and Wildlife Service, Canberra.

Huntley, J. 2012. Taphonomy or paint recipe: In situ portable x-ray fluorescence analysis of two anthropomorphic motifs from the Woronora Plateau, New South Wales. Australian Archaeology 75:78-94. doi.org/10.1080/03122417.2012.11681952

Huntley, J., H. Brand, M. Aubert and M.J. Morwood 2014. The first Australian synchrotron powder diffraction analysis of pigment from a Wandjina motif in the Kimberley, Western Australia. Australian Archaeology 78:33-38. doi.org/10.1080/03122417.2014.11681996

Jelinek, J.J. 1986. The Great Art of the Early Australians: The Study of the Evolution and Role of Rock Art in the Society of Australian Hunters and Gatherers. Moravian Museum Anthropos Institute, Brno.

Jones, R. (ed.) 1985. Archaeological Research in Kakadu National Park. Special Publication 13. Australian National Parks and Wildlife, Canberra.

Kamminga, J. and H. Allen. 1973. Report of the Archaeological Survey: Alligator Rivers Environmental Fact-Finding Study. Government Printer, Darwin.

Kaufmann, D. 1998. Measuring archaeological diversity: An application of the Jackknife Technique. American Antiquity 63(1):73-85. doi.org/10.2307/2694777

Kintigh, K.W. 1984. Measuring archaeological diversity by comparison with simulated assemblages. American Antiquity 49(1):44-54. doi.org/10.2307/280511

Kintigh, K.W. 1989. Sample size, significance and measures of diversity. In R.D. Leonard and G.T. Brown (eds), Quantifying Diversity in Archaeology, pp. 25-84. Cambridge University Press, Cambridge.

Lamb, L. and C. Clarkson 2005. Lithics 'Down Under': Australian Perspectives on Lithic Reduction, Use and Classification. Archaeopress, Oxford.

Lees, B.G. and A. Clements 1987. Climatic implications of chenier dates in northern Australia. Radiocarbon 29(3):311-317. doi.org/10.1017/S003382220004371X 
Lewis, D.J. 1988. The Rock Paintings of Arnhem Land, Australia: Social, Ecological and Material Culture Change in the Post-Glacial Period. International Series S415. British Archaeological Reports, Oxford.

Lyman, R.L. and M.J. O’Brien 2006. Measuring Time with Artifacts: A History of Methods in American Archaeology. University of Nebraska Press, Lincoln.

May, S.K. and I. Domingo Sanz 2010. Making sense of scenes. Rock Art Research 27(1):35-42.

May, S., P.S.C. Taçon, D. Wesley and M. Travers 2010. Painting history: Indigenous observations and depictions of the other in Northwestern Arnhem Land. Australian Archaeology 71:57-65. doi.org/10.1080/03122417.2010.11689384

May, S.K., P.S.C. Taçon and M. Pearson 2011. Painted ships on a painted landscape. In M. Thomas and M. Neale (eds), Exploring the Legacy of the 1948 American-Australian Scientific Expedition to Arnhem Land, pp. 1-23. ANU E Press, Canberra.

McCarthy, F.D. 1965. The Northern Territory and central Australia: Report from the Select Committee on the Native and Historical Objects and Areas Preservation Ordinance 1955-1960, together with minutes of proceedings of the committee. Unpublished manuscript, AIATSIS, Canberra.

McDonald, J. 2015. I must go down to the sea again: Or, what happens when the sea comes to you? Murujuga rock art as an environmental indicator for Australia's north-west. Quaternary International 385:124-135. doi.org/10.1016/j.quaint.2014.10.056

McDonald, J. and P. Veth 2013. Rock art in arid landscapes: Pilbara and Western Desert petroglyphs. Australian Archaeology 77:66-81.

McDonald, J., K.L. Steelman, P. Veth, J. Mackey, J. Loewen, C.R. Thurber and T.P. Guilderson 2014. Results from the first intensive dating program for pigment art in the Australian arid zone: Insights into recent social complexity. Journal of Archaeological Science 46:195-204. doi.org/10.1016/j. jas.2014.03.012

Meehan, B., S. Brockwell, J. Allen and R. Jones 1985. The wetland sites. In R. Jones (ed.), Archaeological Research in Kakadu National Park, pp. 103-153. Special Publication 13. Australian National Parks and Wildlife, Canberra.

Mountford, C.P. 1956. Records of the American-Australian Scientific Expedition to Arnhem Land: Volume 1 - Art, Myth and Symbolism. Melbourne University Press, Melbourne.

Mountford, C.P. 1964. Aboriginal Paintings from Australia. Collins, London.

Mountford, C.P. 1965. Aboriginal Art. Longmans, Green and Company, Croydon.

Mountford, C.P. 1975. The Aborigines and their Country. Rigby, Adelaide.

Mowat, F. 1994. Size really does matter: Factors affecting shell size fragmentation. In M. Sullivan, S. Brockwell and A. Webb (eds), Archaeology in the North: Proceedings of the 1993 Australian Archaeological Association Conference, pp. 201-212. North Australia Research Unit, The Australian National University, Darwin.

Mowat, F. 1995. Variability in western Arnhem Land shell midden deposits. Unpublished Masters thesis, Northern Territory University, Darwin.

Moyle, A.M. 1981. The Australian didjeridu: A late musical intrusion. World Archaeology 12(3):321-331. doi.org/10.1080/00438243.1981.9979807 
Needham, R.S. 1984. Alligator Rivers, Northern Territory. 1:250,000 Geological Series Explanatory Notes. Bureau of Mineral Resources, Geology and Geophysics. Australian Government Publishing Service, Canberra.

Nott, J. 2003. Kakadu-Arnhem Land Region, Northern Territory. Cooperative Research Centre for Landscape Environments and Mineral Exploration, Kensington. crcleme.org.au/RegLandEvol/ KakaduArnhem.pdf

Reimer, P., E. Bard, A. Bayliss, J. Beck, P. Blackwell, C. Ramsey, C. Buck, H. Cheng, R. Edwards, M. Friedrich, P. Grootes, T. Guilderson, H. Haflidason, I. Hajdas, C. Hatte, T. Heaton, D. Hoffmann, A. Hogg, K. Hughen, K. Kaiser, B. Kromer, S. Manning, M. Niu, R. Reimer, D. Richards, E. Scott, J. Southon, R. Staff, C. Turney and J. van der Plicht 2013. IntCal13 and Marine13 radiocarbon age calibration curves 0-50,000 years cal BP. Radiocarbon 55(4):1869-1887. doi.org/10.2458/azu_js_rc.55.16947

Roberts, R.G., R. Jones and M.A. Smith. 1990. Thermoluminescence dating of a 50,000-year-old human occupation site in northern Australia. Nature 345:153-156. doi.org/10.1038/345153a0

Rosenfeld, A. and C. Smith 1997. Recent developments in radiocarbon and stylistic methods of dating rock art. Antiquity 72(272):405-411. doi.org/10.1017/S0003598X00085008

Russell-Smith, J. 1985a. A record of change: Studies of Holocene vegetation history in the South Alligator River region. Proceedings of the Ecological Society of Australia 13:191-202.

Russell-Smith, J. 1985b. Studies in the jungle: People, fire and monsoon forest. In R. Jones (ed.), Archaeological Research in Kakadu National Park, pp. 241-267. Special Publication 13. Australian National Parks and Wildlife Service, Canberra.

Russell-Smith, J., D. Lucas, M. Gapindi, B. Gunbunuka, N. Kapirigi, G. Namingum, K. Lucas, P. Giuliani and G. Chaloupka 1997. Aboriginal resource utilization and fire management practice in western Arnhem Land, monsoonal northern Australia: Notes for prehistory, lessons for the future. Human Ecology 25(2):159-195. doi.org/10.1023/A:1021970021670

Sandercock, P. and K. Wyrwoll 2005. The historical and palaeoflood record of Katherine River, northern Australia: Evaluating the likelihood of extreme discharge events in the context of the 1998 flood. Hydrological Processes 1(20):4107-4120. doi.org/10.1002/hyp.5875

Schrire, C. 1982. The Alligator Rivers: Prehistory and Ecology in Western Arnhem Land. Terra Australis 7. Department of Prehistory, Research School of Pacific Studies, The Australian National University, Canberra.

Senior, B.R. and P.G. Smart 1976. Coburg Peninsula - Melville Island, Northern Territory. 1:250,000 Geological Series Explanatory Notes. Bureau of Mineral Resources, Geology and Geophysics. Australian Government Publishing Service, Canberra.

Shine, D., D. Wright, T. Denham, K. Aplin, P. Hiscock, K. Parker and R. Walton 2013. Birriwilk Rockshelter: A mid- to late Holocene site in Manilikarr country, southwest Arnhem Land, Northern Territory. Australian Archaeology 76:69-78. doi.org/10.1080/03122417.2013.11681967

Smith, M.A., A. Watchman and J. Ross 2009. Direct dating indicates a mid-Holocene age for archaic rock engravings in arid central Australia. Geoarchaeology 24(2):191-203. doi.org/10.1002/gea.20262

Sweet, I.P., A.T. Brakel and L. Carson 1999. The Kombolgie Subgroup - a new look at an old 'formation'. AGSO Research Newsletter 30:26-28.

Taçon, P.S.C. 1988. Identifying fish species in the recent rock paintings of western Arnhem Land. Rock Art Research 5(1):3-15. 
Taçon, P.S.C. 1989a. From Rainbow Snakes to 'X-Ray' Fish: The Nature of the Recent Rock Painting Tradition of Western Arnhem Land, Australia. Unpublished PhD thesis. The Australian National University, Canberra.

Taçon, P.S.C. 1989b. From the 'Dreamtime' to the present: The changing role of Aboriginal rock paintings in western Arnhem Land, Australia. The Canadian Journal of Native Studies IX(2):317-339.

Taçon, P.S.C. 1994. Socialising landscapes: the long-term implications of signs, symbols and marks on the land. Archaeology in Oceania 29:117-129.

Taçon, P.S.C. and S. Brockwell 1995. Arnhem Land prehistory in landscape, stone and paint. In J. Allen and J.F. O'Connell (eds), Transitions: Pleistocene to Holocene in Australia and New Guinea. Antiquity 69 Special Number 265:676-695. doi.org/10.1017/s0003598x00082272

Taçon, P.S.C. and C. Chippindale 1994. Australia’s ancient warriors: Changing depictions of fighting in the rock art of Arnhem Land, NT. Cambridge Archaeological Journal 4:211-248. doi.org/10.1017/ S0959774300001086

Taçon, P.S.C., S.K. May, S.J. Fallon, M. Travers, D. Wesley and R. Lamilami 2010. A minimum age for early depictions of Southeast Asian praus in the rock art of Arnhem Land, Northern Territory. Australian Archaeology 71:1-10. doi.org/10.1080/03122417.2010.11689379

Taçon, P.S.C., E. Nelson, C. Chippindale and G. Chaloupka 2004. The beeswax rock art of the Northern Territory: direct dating results and a 'book of record'. Rock Art Research 21(2):155-160.

Taçon, P.S.C., M. Wilson and C. Chippindale 1996. Birth of the Rainbow Serpent in Arnhem Land rock art and oral history. Archaeology in Oceania 31(3):103-124. doi.org/10.1002/j.1834-4453.1996. tb00355.x

Theden-Ringl, F., J.N. Fenner, D. Wesley and R. Lamilami 2011. Buried on foreign shores: Isotope analysis of the origin of human remains recovered from a Macassan site in Arnhem Land. Australian Archaeology 73:41-48.

Thomas, D.H. 1973. An empirical test for Steward's model of Great Basin settlement patterns. American Antiquity 38:155-176. doi.org/10.2307/279362

Thomas, D.H. 1989. Diversity in hunter-gatherer cultural geography. In R.D. Leonard and G.T. Jones (eds), Quantifying Diversity In Archaeology, pp. 85-91. Cambridge University Press, Cambridge.

Veth. P, P. Hiscock and A. Williams 2011. Are Tulas and ENSO linked in Australia? Australian Archaeology 72:7-14. doi.org/10.1080/03122417.2011.11690526

Wasson, R. (ed.) 1992. Modern Sedimentation and Late Quaternary Evolution of the Magela Creek Plain. Research Report 6, Supervising Scientist for the Alligator Rivers Region. Australian Government Publishing Service, Canberra.

Wasson, R.J., L. Furlonger, D. Parry, T. Pietsch, E. Valentine and D. Williams 2010. Sediment sources and channel dynamics, Daly River, northern Australia. Geomorphology 114(3):161-174. doi.org/ 10.1016/j.geomorph.2009.06.022

Watchman, A. 2000. Micro-excavation and laser extraction methods for dating carbon in silica skins and oxalate crusts. In G.K. Ward and C. Tuniz (eds), Advances in Dating Australian Rock-Markings, pp. 35-39. Occasional AURA Publication 10. Australian Rock Art Research Association, Melbourne.

Watchman, A. and R. Jones 2002. An independent confirmation of the 4 ka antiquity of a beeswax figure in western Arnhem Land, northern Australia. Archaeometry 44(1):145-153. doi.org/ 10.1111/1475-4754.00049 
Watchman, A.L., G.L. Walsh, M.J. Morwood and C. Tuniz 1997. AMS radiocarbon age estimates for early rock paintings in the Kimberley, N.W. Australia: Preliminary results. Rock Art Research 14:18-26.

Watchman, A., G.K. Ward, M. Crocombe and K. Mulvaney 2010. Dating of rock paintings in the Wadeye-Fitzmaurice region, Northern Territory. Rock Art Research 27(2):223-228.

Wesley, D. 2013. Firearms in rock art of Arnhem Land, Northern Territory. Rock Art Research 30(2):235-247.

Wesley, D. 2015. Bayini, Macassans, Balanda and Bininj: Defining the Indigenous Past of Arnhem Land through Culture Contact. Unpublished PhD thesis. The Australian National University, Canberra.

Wesley, D., J. McKinnon and J. Raupp 2012. Sails set in stone: A technological analysis of nonIndigenous watercraft rock art paintings in north western Arnhem Land. Journal of Maritime Archaeology 7(2):245-269. doi.org/10.1007/s11457-012-9103-z

Wesley, D., T. Jones and C. Reepmeyer 2014. Pigment geochemistry as chronological marker: The case of lead pigment in rock art in the Urrmarning 'Red Lily Lagoon' rock art precinct, western Arnhem Land. Australian Archaeology 78:1-9. doi.org/10.1080/03122417.2014.11681993

Woodroffe, C. 1988. Changing mangrove and wetland habitats over the last 8000 years, northern Australia and Southeast Asia. In D. Wade-Marshall and P. Loveday (eds), Floodplains Research, Northern Australia: Progress and prospects Volume 2, pp. 1-33. North Australia Research Unit, The Australian National University, Darwin.

Woodroffe, C., J.M.A. Chappell, B.G. Thom and E. Wallensky 1985a. Geomorphology of the South Alligator tidal river and plains, Northern Territory. In K.N. Bardsley, J.D.S. Davie and C.D. Woodroffe (eds), Coasts and Tidal Wetlands of the Australian Monsoon Region, pp. 3-16. Mangrove Monograph 1. North Australia Research Unit, The Australian National University, Darwin.

Woodroffe, C., J.M.A. Chappell, B.G. Thom and E. Wallensky 1985b. Stratigraphy of the South Alligator tidal river and plains, Northern Territory. In K.N. Bardsley, J.D.S. Davie and C.D. Woodroffe (eds), Coasts and Tidal Wetlands of the Australian Monsoon Region, pp. 17-30. Mangrove Monograph 1. North Australia Research Unit, The Australian National University, Darwin.

Woodroffe, C., J.M.A. Chappell, B.G. Thom and E. Wallensky 1986. Geomorphological Dynamics and Evolution of the South Alligator Tidal River and Plains, Northern Territory. Mangrove Monograph 3. North Australia Research Unit, The Australian National University, Darwin.

Woodroffe, C., B.G. Thom, J.M.A. Chappell, E. Wallensky, J. Grindrod and J. Head 1987. Relative sea level in the South Alligator River region, north Australia, during the Holocene. Search 18:198-200.

Woodroffe, C., J.M.A. Chappell and B.G. Thom, 1988. Shell middens in the context of estuarine development, South Alligator River, Northern Territory. Archaeology in Oceania 23:95-103. doi.org/ 10.1002/j.1834-4453.1988.tb00196.x

Woodroffe C.D., M.E. Mulrennan and J.M.A. Chappell 1993. Estuarine infill and coastal progradation, southern van Dieman Gulf, Northern Australia. Sedimentary Geology 83:257-275. doi.org/10.1016/ 0037-0738(93)90016-X 
This text is taken from The Archaeology of Rock Art in Western Arnhem Land, Australia, edited by Bruno David, Paul Taçon, Jean-Jacques Delannoy and Jean-Michel Geneste, published 2017 by ANU Press, The Australian National University, Canberra, Australia.

dx.doi.org/10.22459/TA47.11.2017.02 